\title{
PETROGLIFOS DO ESTILO DE PISADAS NO RIO GRANDE DO SUL
}

Josẻ Proenza Brochado

Pedro Ignicio Schmitz

\section{I - INTRODUÇÃo}

O planalto meridional do Brasil - constituido de arenitos da formaçăo Botucatu recobertos por derramamentos de lavas basálticas da Serra Geral - cobre a metade norte do território do Estado do Rio Grande do Sul, O planalto finda de maneira abrupta por uma escypa ou cuesta, que se volta para o sul e o leste e alcança altitudes ao redor de $400 \mathrm{~m}$ s.n.m. A seu pé encontra-se uma zona de circundenudaçūo, constituida de sedimentos paleozótcos, jrea de releve muito suave cujas altitudes médias se encontram ao redor de $100 \mathrm{~m}$ s.n.m." A escarpa do planalto se apresenta como um degrau único, levantado, emergindo diretamente da planície costeira e da peneplanicie, porém a modelagem a que foi submetida pelo trabalho de drenagen dos rios Jacui, Ibicui-Mirim e seus tributários, cortou em alguns pontos a escarpa, que se apresenta então dissecada pelas denominadas bocas de serra. ${ }^{2}$

Nas cetcanias das bocas de serra do Jacuí e do Toropi foram encontradas em quatro lugares diferentes trés abrigos e duas grutas, em cujas paredes e teto se observam petroglifos. Os abrigos e grutas foram escavados por agentes naturais em blocos ou lajes de arenito da formaçáo Botucatu que se encontram destacados alguns quilometros adiante do alinharnento principal da escarpa.

\section{RS-MJ-15: Gruta de Canhemoorí \\ RS-MJ-102: Gruta do lajeado dos Dourados. \\ RS-MJ-53-A e B; Abrigos da linha Sétima. \\ RS-SM-7: Abrigo da Pedra Grande.}

Como a drea se encontra sobre os $29^{\circ} 30^{\prime}$ de latituds sul e entre os $53^{\circ} 15^{\prime}$ e os $54^{\circ} 15^{\circ}$ de longitude oeste, seu clima ế sabtropical úmido mesotérmico sem estação seca e com veróes quentes: Cfa, segundo a classificaçāo de Koppen. ${ }^{3} \mathrm{O}$ regime pluviométrico apresenta chuvas distribuidas durante todo o ano, com máximas no outono $e$ inverno, variando entre $1500-1750 \mathrm{~mm}$. As temperaturas medias anuais se encontram dentro da isoterma de $18^{\circ} \mathrm{C}$. Os veroes sào quentes e os invernos rigorosos, com as médias das miximas e das mínimas entre $22^{\circ}$ e $24^{\circ} \mathrm{C}$ no verajo, e entre $12^{\circ}$ e $14^{\circ} \mathrm{C}$ no inverno. A amplitude térmica ê da ordem de $11^{\circ} \mathrm{C}$. As geadas ocorrem com a frequềncia média de uns 10 dias por ano. A umidade relativa do ar se acha ao redor dos 80 a $85 \%{ }^{4}$ No tocante à possibilidades da vegetação, a área pertence a região bioclimática eumesaxérica (temperada) 7.a, conforme a classificaçāo de Gaussen! ${ }^{5}$ Entretanto, como as formaçōes 
florestais e campestres ocorrem, respectivamente, em funçāo direta dos acidentes e invera da irrigaçio do terreno, ali se encontra o limite entre a floresta latifoliada tropical que anteriormente recobria a escarpa e os campos cobertos de gramíness que se estendem para o sul. ${ }^{6}$

Todos os abrigos e grutas estudados neste trabalho se encontram dentro desta floresta da escarpa.

A encosta do planalto meridional voltada para o sul, entre o Jacuí e Ibicui-Mirim, vem sendo pesquisada desde 1968 pela equipe do Gabinete de Arqueologia do Instituto de Filosofla e Clências Humanas da Universidade Federal do Rio Grande do Sul, Entre 1969 e 1972, os cinco abrigos e grutas foram escavados e seus petroglifos foram coplados pela mesma equipe, em conjunto com a do Instituto Anchietano de Pesquisas da Universidade do Rio dos Sinos (UNISINOS), dirigidas pelos dois autores.

\section{II - PUBLICAÇŌES ANTERIORES}

Una das agrupaçôes dos petroglifos do abrigo da Pedra Grande, chamado entāo de Ribeirảo, foi fotografada, em 1935, por Vicentino Prestes de Almeida. Em 1936, Antonio Serrano publicou estas fotografias, ${ }^{7}$ que foram reproduzidas por Anibal Mattos. ${ }^{8}$ As mesmas fotografias foram outra vez pablicadas por $J$. Tupi Caldas, que tentou "traduzir" alguns dos motivos"

Em 1969, o abrigo foi redescoberto pelos PP. Jost Pivetta e Daniel Cargnin, do Museu do Patronato Agrícola Antonio Alves Ramos de Santa Maria e no mesmo ano foi publicada uma breve notícia a respeito dos petroglifos da gruta de Canhembora. ${ }^{10}$ Em 1971 , os petroglifos e a indústria lítica da gruta de Canhemborá e dos abrigos da Sétima (A e B) e da Pedra Grande foram muito sumariamente descritos no que se chamou a fase Canhemborá." Em 1972, a fase Canhemborá passou a incluir somente as manifestaçōes mais antigas das grutas de Canhembora e do lajeado dos Dourados e do abrigo da Pedra Grande. $^{12}$

A ceraimiea do situo superficial localizado atrás do abrigo da Pedra Grande fez inicialmente parte da subfase B da fase Vacacai ${ }^{13}$ da tradiçăo Tupiguarani. ${ }^{14}$ Depois se criou con esta cerămica e a de outros śtios a fase Reduçōes, ${ }^{15}$ colocandóa na transição da cerâmica da tradị̄āo Tupiguarani para a Neobrasileira. ${ }^{\text {Th }}$

Comunicaçóes pessoais do primeiro dos autores a respeito dos petroglifos da gruta de Canhemborá e do abrigo da Pedra Grande, chamada também Laje de Pedra, foram publicadas por Pedro A. Mentz Ribeiro nas comparaçbes que fez com as petroglifos que estudou em outros locais. ${ }^{17}$ 


\section{III - DESCRIÇẴO}

RS-MJ-15: Gruta de Canhemborá

A gruta de Canhemborá se abre num paredão orientado do noroeste para o sudeste, incalizado uns $200 \mathrm{~m}$ ao norte da margem direita do rio Jacul que neste local, ao descer do planaito, corre do norte para o sul, antes de dobrar para leste e desaguar ma laguna dos Patos. Encontra-se a $7 \mathrm{~m}$ de altura sobre o nivel do vale e o talude da sua entrada é muito empinado; $600 \mathrm{~m}$ a sudeste do arroio Bugre, afluente do Jacuí, e um quilòmetro a leste da povosçăo de Canhembori.

A gruta está orientada para o noroeste e mede $10,8 \mathrm{~m}$ de largura, $7,7 \mathrm{~m}$ de profundidade e $2,8 \mathrm{~m}$ de altura máxima na entrada. $O$ teto se inclina tơo rapidamente para o interior e lateralmente que a área disponivel para a ocupaçấo humana, com forma trimgular, mede apenas $6,5 \mathrm{~m}$ de largura e $4 \mathrm{~m}$ de comprimento, se restringindo, portanto, a uns $26 \mathrm{~m}^{2}$ (Fig. 3).

A erosão formou concavidades menores nas paredes da gruta, uma das quais ê alaalmente praticável, comunicando com uma cimara menot.

As esfoliaçōes causadas pela queda de grandes lajes e blocos do teto, deixaram uma série de superficies planas, verticais e horizontais, escalonadas, que formam como que dois degraus invertidos. Nas faces mais ou menos verticais destes dois degraus, muito visiveis desde a entrada, é que se observa as majores concentraçöes de petroglifos. Porém, outras concentraçdes menores se distribuem também, em painéis descontínuos $\mathrm{e}$ isolados, nas faces horizontais dos degraus, na superficie inclinada de uma espécie de balcalo ligado A. parede lateral direita e até na face de um bloco triédrico, possivelmente caído do teto. atualmente jazendo sobte o solo ra entrada, A superficie total ocupada pelos diferentes painéis de petroglifos pode ser calculada $\mathrm{cm} 2,5 \mathrm{~m}^{2}$. Observam-se também as cicatrizes deixadas pela retirada de motivos inteiros pot colecionadores da regjāo, ${ }^{18}$

\section{Técaica}

Todos os petroglifos da gruta șio gravados, porém se observam duas técnicas distintas de gravaçato: uma por picoteamento e raspagem e a outra por polimento. 0 picoteamento, executado com a ponta de um instrumento aguçado, criou pequenas depressoes contínuas e alinhadas que foram reunidas pela raspagem, formando sulcos que apresentam bordas ondulantes e irregulares. Os sulcos polidos, ao contrário, aptesentavam secça em V mais ou menos obtusa e bordas bem definidas, em bisel. Os sulcos medem desde $3 \mathrm{~mm}$ até $2 \mathrm{cra}$ de largura, com profundidades correspondentes à largura, porque, de maneira geral, quando foram feitos por martelamento, são mais largos a rasos, e quando polidos, mais estreitos e profundos. Além dos sulcos se observam também depressōes e perfuraçōes que medem desde não mais de $5 \mathrm{~mm}$ até $10 \mathrm{~cm}$ de diàmetro, com profunds. dades desile $5 \mathrm{~mm}$ até 2 ou $3 \mathrm{~cm}$.

Alguns dos sulcos, depressīes e perfuraçôes apresentam restos de pigmentos de cor em seu interior. A cor mais comum é o preto, seguindo-se o verde; em menor quantidade, 
se observam também tonalidades mais claras como o branco, porém sĩo raras as mais escuras como o marrom e o roxo. A aplicaçăo do pígmento se fez possivelmente de duas maneiras: (a) pela fricç̄̄o com um fragmento de mineral duro da cor desejada, que seria o mesmo instrumento que serviu também para concluir a gravaçăo, resultando uma supes. ficie polida ande foi depositado o pigmento; (b) pela friçẫo com um fragmento mais brando ou dissolvido, que poderia ser um pedaço bem macerado do mesmo mineral que em (a).

\section{Motivos (Fig. 1 e 2)}

Osmotivos gravados podem ser resumidamente descritos como segue:

1) Depressodes circulares rasas, rodeadas em parte por quatro ou seis depressóes menores, sugerindo as pegadas de um felino. As dimensōes da depressăo central variam desde 12 até $14 \mathrm{~cm}$. As pegadas sempre se alinham no sentido de marcha do animal, senz, no entanto, representar todo o rastro como ele o deixaria, com as impressర̄es de saas quatro extremidades. Os rastros, começando a mais de $1 \mathrm{~m}$ de altura acima do nivel atual do piso da grata, sobem pelas paredes şegando até o teto. A maior parte das pegadas estāo internamente pintadas de preto ou cinza-chumbo, mais raramente de tonalidades mais claras como o verde ou o branco.

2) Très sulcos retilíneos convergentes ou um sulco curvo, em meia-lua, cortado na metade por um outro sulco retilineo e vertical, sugerindo pisadas de ave. $\mathrm{O}$ sulco maior mede entre $12 \mathrm{e} 15 \mathrm{~cm}$. Algumas se acham pintadas, outras nãa. Geralmente se alinham no mesmo sentido e direção dos rastros dos felinos.

3) Duas depressoes elipticas rasas emparelhadas, sugerindo pegadas de um animal de casco fendido.

4) Suleos circulares ou elípticos com uma perfuração ou suleo vertical no centrs. sugerem simbolos sexuais femininos, como sāo frequentemente representados em petroglifos de diversas áreas do mundo. Quase sempre o interior dos sulcos está pintado de preto.

5) Sulcos retilíneos verticais paralelos, alinhados perto dos motivos anteriores, poderiam representar simbolos sexuais masculinos como os que slo encontrados frequentemente em companhia dos primeiros em petroglifos de diversas áreas do mundo. Há dois conjuntos semelhantes nesta gruta.

6) Suleos retilíneos verticais paralelos, alinhados num longo registro, cancelados na parte de cima por um sulco horizontal e terminados na parte de baixo por trés flleiras de pequenas perfuraçòes alinhadas. $O$ conjunto lembra franjas ou uma cerca.

7) Um sulco circular com uma perfuraçáo central e sulcos retilineos irradiando di sua periferia, dois pela parte de cima e uma pela de baixo.

8) Um sulco ondulante horizontal, recordando uma serpeate.

9) Suleos mistilíneos ou meaindricos, compostos de linhas curvas e retas combinadas.

10) Perfuraçoes circulares de dimensoes variadas, isoladas ou alinhadas. 


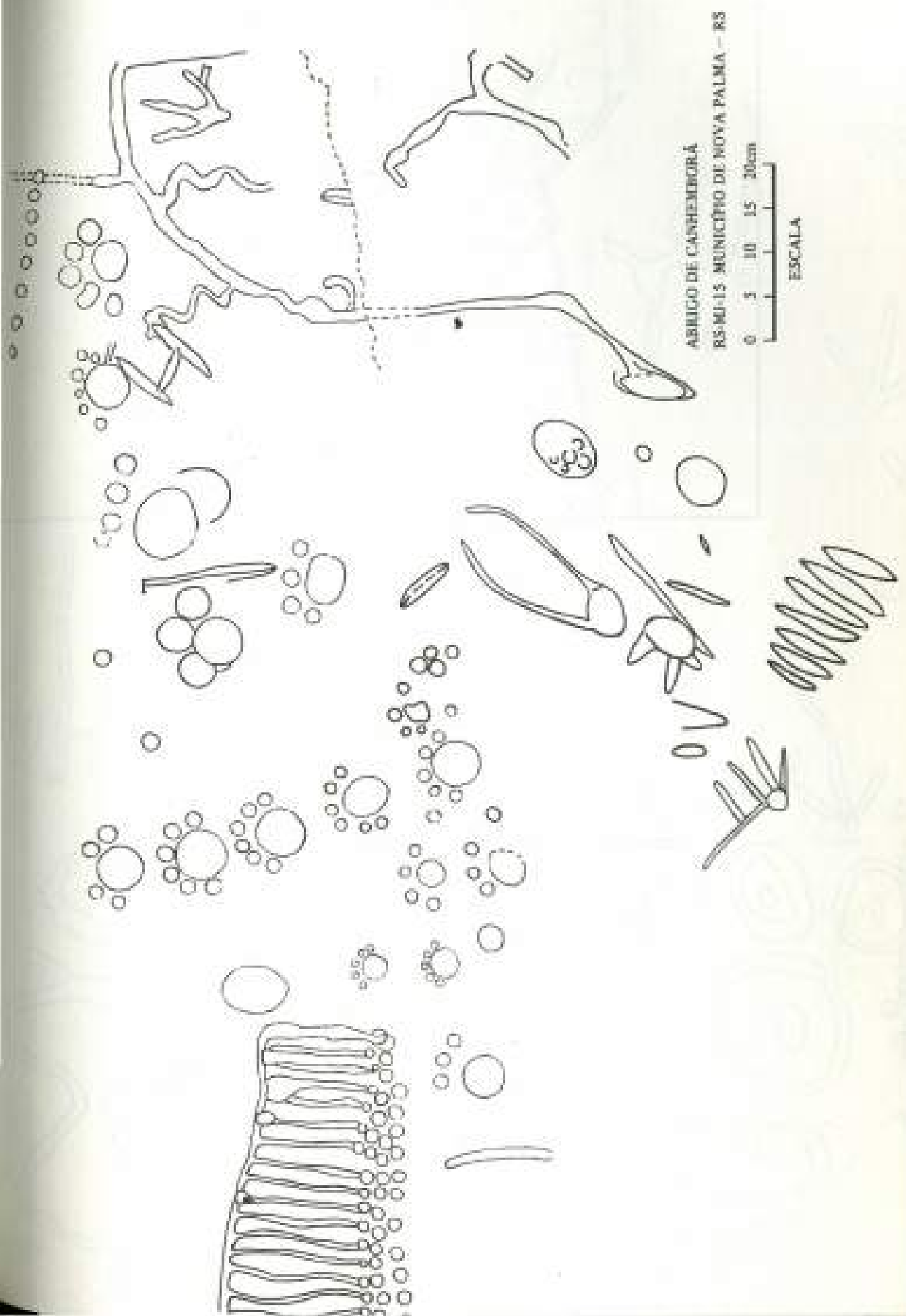




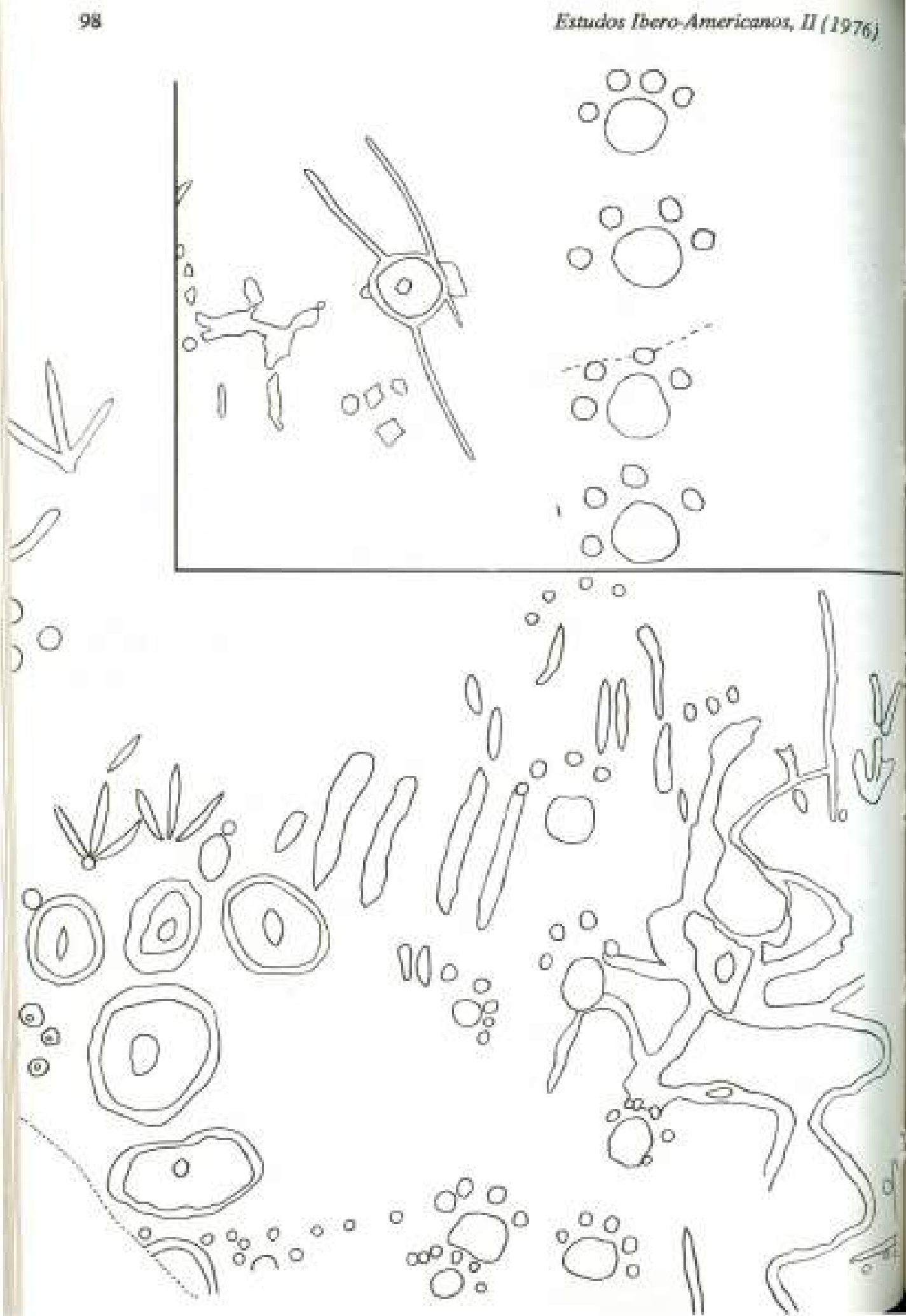




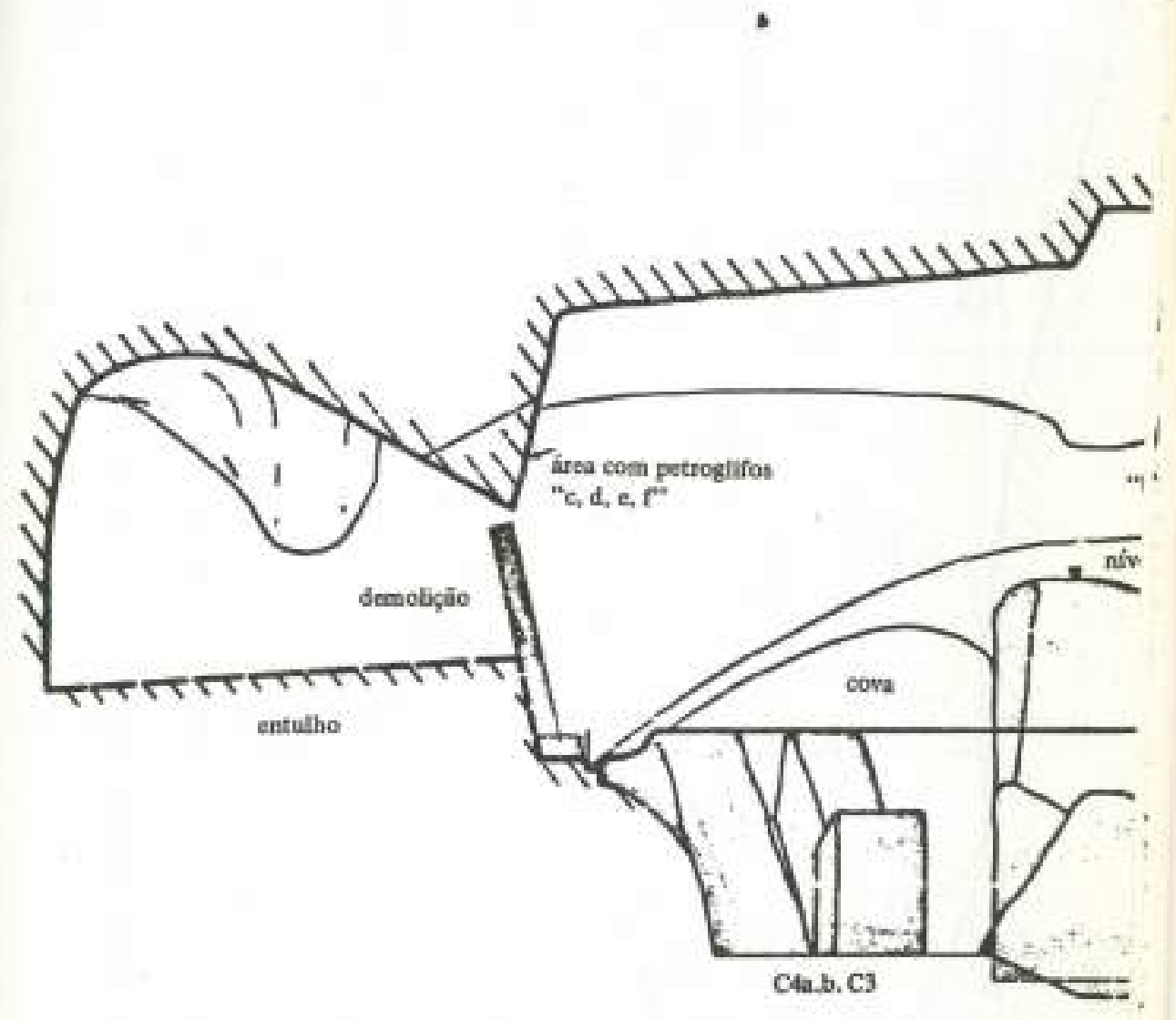




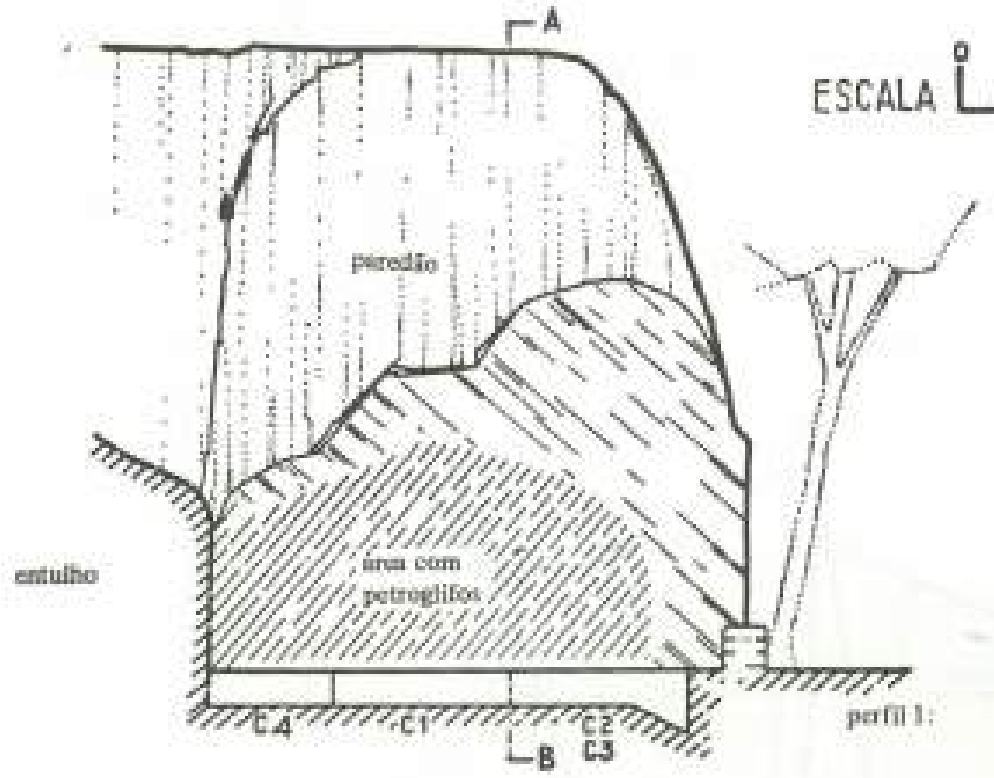

VISTA

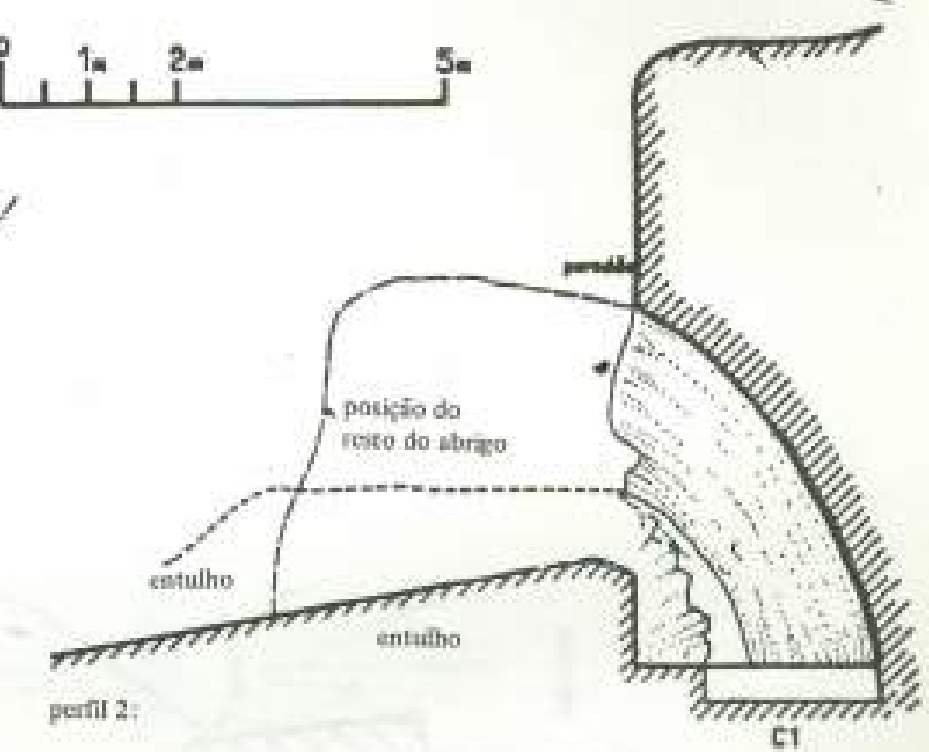

CORTEA-I

ercai a $\{20406090.0 \%$ 


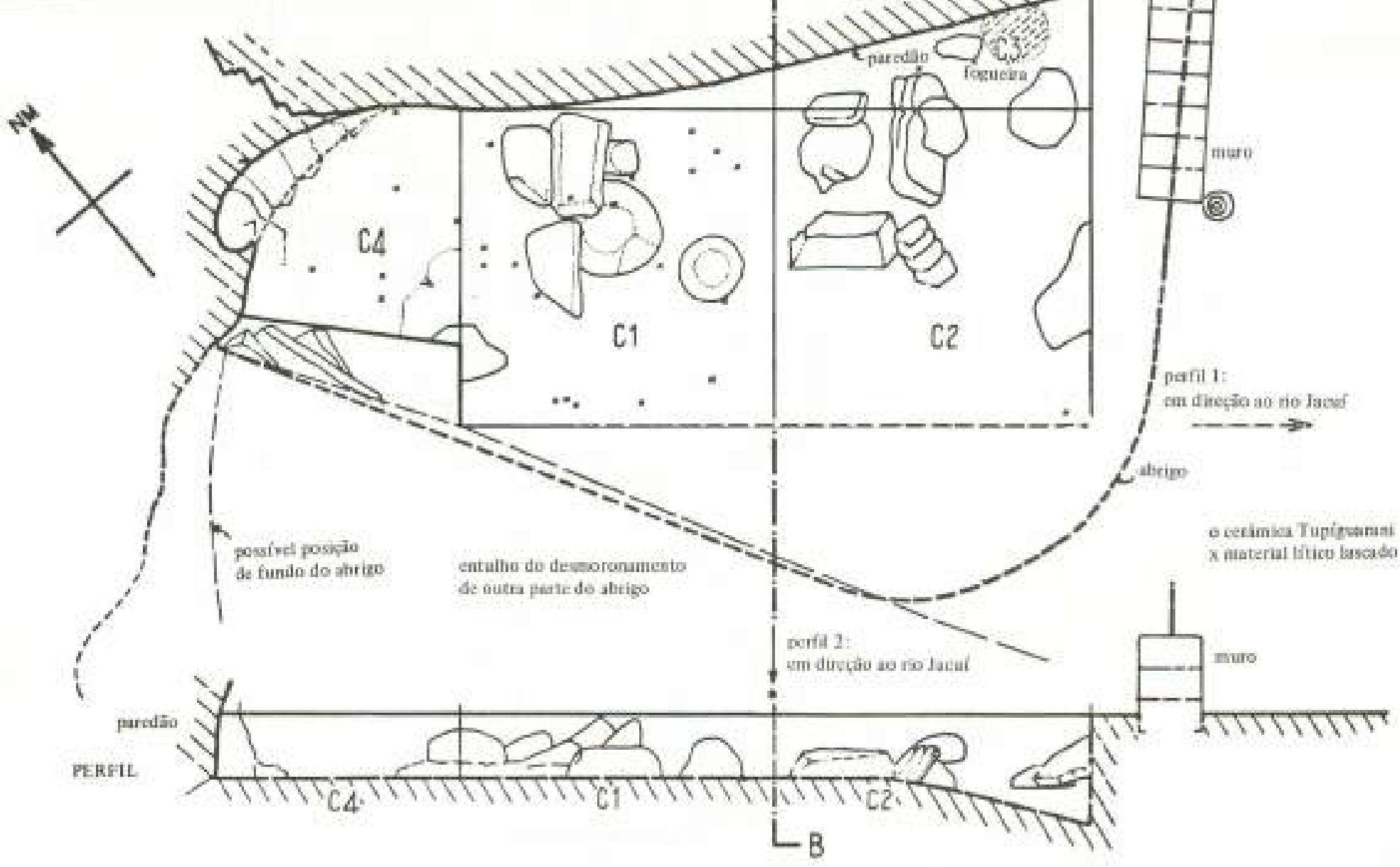




\section{Petroglufos... ,}

Segundo a classifieação de motivos da arte rupestre proposta por C.J. Gradin, ${ }^{19}$ c5 motivos 1,2 e 3 seriam representativos estilizados biomorfos; 4,5 e 8 seriam representativos esquematizados biomorfos; 6 , abstrato geométrico retilineo; 0 7, abstrato live formatizado; o 9 seria abstrato livre caprichoso e o 10, abstrato puntiforme isolado.

Foi possivel observar que algumas gravuras' se sobrepdem a outras, indicando que nto foram todas executadas ao mesmo tempo.

\section{Escamẹto}

A gruta de Canhemborí foi visitada pela primeira vez em 1969, Dois poços estratigráficos foram escavados em 1969 e 1970. Em 1971, como o solo e as paredes da gruta já tinham sido parcialmente prejudicados por escavaçđ̄es nắo autorizadas feitas por eaçadores de tesouros, o seu conteúdo foi inteiramente escavado. ${ }^{30}$

O interior da gruta se encontra atravancado por muitas lajes e blocos esfoliados do teto ou das paredes, a maioria paralelepipédicos ou prismáticos, os quais medem desde ao redor de $70 \times 40 \times 30 \mathrm{~cm}$ até um que mede cerca de $3 \mathrm{~m}$ de comprimento, $4 \mathrm{~m}$ de largara e $2 \mathrm{~m}$ de altura $e$ ocupa aproximadamente o seu centro e não pöde ser removido. Desta mancira, dos cerca de $26 \mathrm{~m}^{2}$ de área utilizável para ocupação, somente foi possivel escavar pouco mais de $12 \mathrm{~m}^{2}$ (Fig. 3).

A area escavada foi dividida em cinco quadriculas contiguas que tiveram de ter dimensōes variiveis para se acomodarem aos espaços existentes entre os blocos $(\mathrm{C} 2, \mathrm{C} 3$, $\mathrm{C} 4 . \mathrm{a}, \mathrm{C} 4, \mathrm{~b}, \mathrm{C} 4 . \mathrm{c}, \mathrm{C} 5, \mathrm{C} 6 \mathrm{)}$.

Observou-se que o interior da gruta estava preenchido por sedimentos até o ponto que a superfície atual do piso, relativamente horizontal, recobria todos os blocos, exceto o maior deles que sobressaia ainda $70 \mathrm{~cm}$ e no topo do qual foi localizado o datum do nivelamento.

A camada arqueológica se compunha de sedimentos finos arenosos, resultantes da decomposição natural do arenito. Continha ainda grande quantidade de fragmentos e blocos de menotes dimensōes apenas parcialmente decompostos e apresentava coloraçâo e texturs muito variáveis, segundo a situação das quadriçulas.

Nas quadrículas escavadas em áreas protegidas do interior da gruta, os sedimentos se apresentavam secos $e$ friáveis $e$ tinham coloraçio clan: amarelada ou rosada. Na quadriculi escavada na entrada, mal protegida pela aba do teto e nos locals onde havia infiltraçðes de água, os sedimentos se encontravam úmidos, compactados ou nšo, e apresentavam coloração escura: cinza ou marrom.

O solo estéril subjacente se compōe de arenito em decomposip̧̄o e apresenta muitas fendas. $O$ piso natural era também aproximadamente horizontal, apesar de irregular e se tncoatrava em média entre $70 \mathrm{~cm}$ a $1 \mathrm{~m}$ abaixo do piso atual. A espessura da camada arqueológica variou desde $40 \mathrm{~cm}(\mathrm{C} 4 . \mathrm{b}, \mathrm{C} 4 . \mathrm{c})$ até $130 \mathrm{~cm}$ (C4.a, C5),com uma média entre $70 \mathrm{~cm}$ c $1 \mathrm{~m}$. Esta variação se deve ao fato de que, exceto na entrada, os depósitos preenchiam os espaços, às vezes muito estreitos, entre os grandes blocos, ou as concavidades existentes debaixo destes. 
A escavação foi executada por niveis artificiais de $10 \mathrm{~cm}$ de espessura cada um, tendo sido levada sempre até o piso natural, contando-se, portanto, desde quatro até treze destes niveis por quadricula. A estratigrafia do interior da gruta parece indicar várió episódios sucessivos de quedas de blocos do teto, preenchimento por sedimentos ocupsçōes humanas, diff́ceis de serem reconstruídos devido a sua complexidade.

\section{Material arqueológico}

A indústria lítica recuperada está constituída por instrumentos lascados, polidos, ou picoteados. A matéria-prima utilizada foram as rochas vuleânicas da regiăo: basaltos e quartzos, estes sob a forma cristalina ou de calcedônia, igata etc, ou arenitos metamorfizados.

Foi possivel identificar os seguintes instrumentos:
a) Grandes bifaces alongados.
b) Raspadotes altos e baixos laterais ou terminais, alguns deles denticulados.
c) Lascas retocadas como facas ou raspadores.
d) Percutores.
e) Lascas retocadas.
f) Machados polidos somente no gume.
g) Bola de boleadeira executada por picoteamento, com saleo.
h) Mos ou trituradores feitos pot picoteamento. Uma delas apresentava ainda, aderido as suas faces, restos de pigmento preto semelhante ao utilizado na pintura das gravuras:

Além destes, existem:

i) Grandes seixos planos, provavelmente utilizados como bigornas.

j) Seixos lascados pelo fogo que poderiam ter sido pedras termóforas.
k) Fragmentos aguçados de tochas corantes que poderiam ter sido utilizados para colorir e polir os sulcos dos petroglifos.

Finalmente havia:

1) Alguns núcleos $\mathrm{e}$ grande quantidade de restos de lascamento.

m) Muitos nódulos de matéria-prima, alguns lascados intencionalmente e cutros sem sinal de utilizsção.

Foram encontrados alguns poucos fragmentos de cerâmica da tradiçāo Tupiguarani ${ }^{21}$ nos dois primeiros niveis de algumas das quadrículas, isto 6 , at Por suas dimeasōes, pertenciam a vasilhas pequenas.

Foram muito poucas as evidèncias calturais ou estruturas observadas; somente alguns indícios de fogueiras que continham earvaso e cinzas. ${ }^{23}$ 


\section{Dataçōes}

Temos duas dataçoes radiocarbònicas:

$$
\begin{array}{llll}
1165 \pm 35 \text { a.P. } & \text { A.D } .750-820 & (\mathrm{C} 5,40-50 \mathrm{~cm}) & (\mathrm{SI}-1000)^{23} \\
2945 \pm 85 \text { a.P. } & 1080-910 \text { a.C. } & (\mathrm{C} 5,60-70 \mathrm{~cm}) & (\mathrm{SI}-1001)
\end{array}
$$

A posiçîlo estratigráfica das duas dataçōes em níveis quase consecutjvos da mesma quadricula (ver gráflico, Fie 7) indica que devem corresponder a dois momentos distintos e sucessivos de ocupaçăo, separados por mass de mil e seiscentos anos.

Un terceiro momento de ocupação, representado pela presença da cerâmica da tradiçăo Tupiguarani, nos primeiros niveis, somente se pode datar, por intermédio de evidènclas externas ao sítio, conno posterior a ca. A.D. 1100.

A conexão entre os petroglifos e a camada arqueológica se fez através do achado no interior desta de alguns fragmentos de mineral corante com as extremidades aguçadas que parecem ter sido os usudos para pigmentar e polit o interior dos sulcos das gravaçōes. $\mathrm{Na}$ entrada da gruta, foi também fecolhida superficialmente uma mo on triturador que apresenta ainda restos de pigmento preto aderido as suas faces e que poderia ter erodido đa camada arqueológica do talude.

\section{RS-MJ-102: Gruta do lajeado dos Dourndes}

A gruta do lajeado ou arroio dos Dourados se acha a uns $100 \mathrm{~m}$ de distáncia da margem esquerda do rio Jacui. $\mathrm{Na}_{2}$ margem oposta do tio, a menos de $1 \mathrm{~km}$ em linha reta, se ençontra o abrigo da linha Sétima e, $11 \mathrm{~km}$ rio acima, a gruta de Canhemborá.

A gruta do lajeado dos Dourados se abre numa parede vertical, a mais de $20 \mathrm{~m}$ acima do nivel de cheia do rio, o qual aqui corse a uns $50 \mathrm{~m}$ s.n.m. e se encontra imediatamente abaixo do terraço mais alto do vale, por isso o seu talude de entrada é tambem muito empinado,

Está orientada pera sudeste e mede $9 \mathrm{~m}$ de largura na entrada e $7.5 \mathrm{~m}$ de profundidade.

A gruts foi pesquisada em 1972. O seu interior foi bastante modificado pela retirada de blocos para a coastruçalo, o que dificulta o cálculo da área primitivamente disponível para a ocupação humana.

Como na gruta de Canhemborá, as esfoliações causadas pela queda de grandes lajes do teto, deixaram uma série de superfieies planas, verticals $\mathrm{e}$ horizontais que formam como que degraus invertidos, em cujas faces voltadas para a entrada se observam muitos petrogifos. Outra concentraçäo se encontra na parte baixa da parede do fundo. ${ }^{24}$

\section{Técrica}

Pode-se observar que todos es petroglifos da gruta sĭo gravados, porém o processo te eros:so alveolar $e$ as esfoliaçōes da superficie do arenito nas paredes e no teto, assim como as proliferaçōes de líquenes, prejudicoulos de tal maneira que atualmente se 
upresentam muito desgastados e indistintos. Tanto que se toma difícil calcular a área total que teria aido ocupada por eles $e$, no que se refere a técnica com que foram executados, somente se pode dizer que parece ter sido a do polimento. Em geral os sulcos possuen secçâo em $U$ mais ou menos rasa e medem de 1 a $2 \mathrm{~cm}$ de largura, com profundidades correspondentes. As perfuraçoes medem desde $5 \mathrm{~mm}$ até $10 \mathrm{~cm}$ de diämetro, $c 0 \mathrm{~m}$ profundidade desde $5 \mathrm{~mm}$ até mais de $10 \mathrm{~cm}$. As perfuraçóbs menores que se apresentam alinhadas (ver motivo 11, a seguit) devido a sua regularidade e ao polimento do seu interior, parecem ter sido broqueadas por meio de uma ferramenta rotativa.

Os petroglifos não apresentam atualmente restos de pintura, o que pode ser atribuído ao processo erosivo, muito mais intenso do que na gruta de Canhemborá.

\section{Motivos}

Os motivos gravados podem ser resumidamente descritos como segue:

1) Depressōes que sugerem pegadas de felino, porếm menores que as da gruta de Canhembori, pois medem somente uns $6 \mathrm{~cm}$ de diämetro. Algumas se encontram isoladas, outras alinhadas em um único rastro que apresenta a mesma direção e sentido que os de Canhembori.

2) Suleos convergentes que sugerem pegadas de ave.

3) Dois sulcos ondulantes e sinuosos dispostos simetricamente i direita e esquerda do intetior da cova, sugerindo serpentes. Terminam em depressōes ou perfurações, uma delas com sulcos irmadiantes da periferia.

4) Sulcos curvilíneos de grandes dimensioes.

5) Sulcos retilíneos, verticais e paralelos.

6) Dois ou mats suleos retilíneos convergentes, cruzados por outro.

7) Uma perfuraçăo circular com sulcos irradiantes.

8) Sulcos relacionados com depressōes ou perfuraçס̄es, separadas ou alinhadas.

9) Combinaçốes dé sulcos mistilineos, entrecruzados ou năo.

10) Sulcos retilineos verticais e paralelos, limitados por outro pela parte de baixo ou de cima.

11) Perfuraçס̄es cilindricas de várias dimensōes, alinhadas, às vezes desenhando figuras lineares quebradas.

Observa-se que, em genl, predominam os motivos lineares e as perfuraçōes e que estas últimas tendem a se concentrar na parte baixa das paredes.

Os sulcos dos motivos lineares às vezes também contêm perfuraçōes no seu interior. Existe também grande quantidade de perfuraçōes cilindricas de origem natural, resultartes da erosāo alveolar do arenito e ds vezes é difieil distingui-las das perfuraçö́es artificiais. ${ }^{25}$

Tendo em vista a classificação proposta por C J. Gradin, ${ }^{26}$ o motivo 11 seria abstrato puntiforme alinhado; o 3, abstrato geométrico combinado e os motivos 2,6 e 7 serium abstratos livres formatizados. Todos os restantes seriam abstratos geométricos rectlíneos, curvilíneos ou combinados, assim como abstratos livres caprichosos. 
Evearafĭo

O piso da gruta apresenta a própria rocha viva à vista. Apesar das modificaçōes posteriores, á pouco provável que tenham realmente, ocorrido deposiçôes importantes no eu interior. Somente de 5 a $10 \mathrm{~cm}$ de solo arenoso; resultante da decompoxiçäo da mesma wcha, mesclado com folhas secas e esteroo; enchia algumas depressobes do fundo, onde se pode soletar algum material arqueológico acumalado.

No topo do talude da entrada, na parte externa da gruta, foi possivel escavar um poço estratigráfico de $2 \mathrm{~m}^{2}$ que se aprofundou atê os $30 \mathrm{~cm}$ em niveis artificiais de $10 \mathrm{~cm}$ ada um. Na maiot parte da áres do poço que se achaya protegida pelo teto, o solo ora friavel, de colonaçăo cinzenta; mas na parte externa, nāo protegida, o solo se achava compactado e apresentava coloraçăo marrom avermelhada. $O$ depósito continha ainda gande quantidade de fragmentos de arenito näo inteiramente decomposto que aumentava na direção dos níveis mais baixos. O solo estéril era constituido do mesmo arenito em decomposiçĩo.

O material arqueológico se concentrava mais no setor mais protegido da quadricula.

\section{Material arqueológico}

Nas depressōes da rocha do piso se recolheu um biface reto alongado, a extremidade proximal de outro biface, uma lasca trabalhada, além de muitas lascas grandes, médias e pequenas.

No poço estratigráfico se obteve a extremidade distal de um biface e muitas lascas médias e pequenas. A fauna estava representada por grande número de carapaças de caracóts terrestres e alguns ossos de pequenos animais, mamíferos principalmente.

Nšo havia ceraimica na gruta.

\section{RS-MJ-53-A e B: Abrigos da linha Sétima (Fig̨ 4)}

Os dois abrigos são contíguos e se abrem na metade da altura da escarpa de um esporắo rochoso. Est5o distanciados somente $30 \mathrm{~m}$ da margem direita do rio Jacul e se acham respectivamente a $18 \mathrm{e} \cdot 14,5 \mathrm{~m}$ de altura sobre o seu nivel de cheia. Orio Jacuí acuí corre a uns $50 \mathrm{~m}$ s.n.m.

O primeiro abrigo (A), situado à major altura, está orientado para sudeste e mede ahualmente $6 \mathrm{~m}$ de largura, $3 \mathrm{~m}$ de profundidade e $4 \mathrm{~m}$ de altura. Com estas dimensoes representa porém somente a metade direita que restou de uma gruta muito maior que teria pelo menos o dobro da largura do abrigo atual e maior profundidade. $O$ desmoronamento do teto desta gruta teria ocorndo, ao que tudo indica, antes de ter sido ocupada.

Todos os petroglifos se concentram na parede do fundo do abrigo, plana e inclinada para fora, formando um painel que mede $5 \mathrm{~m}$ de largura por $2,5 \mathrm{~m}$ de altura. 
O segundo abrigo (B), orientado para leste, mede $6 \mathrm{~m}$ de largura, $4 \mathrm{~m}$ de profundidade e $4 \mathrm{~m}$ de altura; encontra-se um pouco abaixo do primeiro e somente apresenta alguns petroglifos sobre a superficie plana e horizontal de um grande bloco esfoliado do teto.

\section{Técnica}

Todos os petroglifos foram gravados pela técnica do polimento. Os sulcos apte. sentam secçso em U e medem de 8 a $15 \mathrm{~mm}$ de largura com profundidade entre 10 e $20 \mathrm{~mm}$. As perfuraçōes medem desde $5 \mathrm{~mm}$ até $10 \mathrm{~mm}$ de diämetro, com profundidade desde $5 \mathrm{~mm}$ até $5 \mathrm{~cm}$.

\section{Motivos}

Os motivos gravados no abrigo A podem ser resumidamente descritos como segue:

1) Sulcos retilineos e paralelos, alinhados formando registros nos quais todos $\propto s$ sulcos sfio verticats ou todos horizontais. Alguns destes registros sijo compostos de sulcos compridos, outros de sulcos muito curtos.

2) Sulcos retilineos paralelos verticais, cortados por um ou mais sulcos horizontais: Mais raramente ș̃o horizontais cortados por um ou mais sulcos verticais. Muitas vezes apresentam a aparẻncia de uma grade.

3) Perfuraçōes de dimensōes variãvẹis alinhadas, às vezes desenhando figuras linęres.

4) Sulcos curvos em meia-lua, cortados na metade por outro retilineo e vertical. sugerindo pisadas de uma ave.

5) Duas perfuraçōes circulares com sulcos irradiantes da sua periferia, sugerindo a imagem do sol.

6) Perfuraçoes circulares largas e profundas, isoladas ou agrupadas.

7) Sulcos circulares com uma perfuraçăo central larga e profunda e sulcos elípticos com uma depressāo central alongada.

Predominam 0 sulcos retilíneos e paralelos, entrecruzados em forma de grade es perfuraçōes isoladas ou alinhadas.

Segundo a clussificaçũo proposta por C. J. Gradin, ${ }^{27}$ os motivos podem ser: abstratos puntiformes isolados (6) ou alinhados (3); abstratos geométricos retilíneos (1-2) ou combinados (7), abstratos livres formatizados (5) ou representativos esquematizados biomorfos (4),

No abrigo B existem somente alguns sulcos retilineos verticais paralelos e algumas perfuraçbes circulares de dimensōes variadas. 


\section{Escaragâto}

O abrigo A teria sido oetupado há alguns anos por umasferraria e por uma pocilga, tendo o ses piso sido levantado e aplanado pela adição de fragmentos de arenito compactados e um muro de blocos construido do lado direito para sustentar o talude. A superficie atual se inclina para sudeste, devido a uma nova acumulaçăo de sedimentos eseorridos do alto do paredalo pelo lado oposto, mas a superfície do piso de ocupaghăo subjacente era horizontal, se inclinando para baixo somente no ängulo sul.

Em 1969, foi executado um poço estratigráfico junto à parede do fundo đo abrigo e, em 1972, a área protegida pelo teto foi totalmente escavada, ${ }^{28}$ A área total, dividida $\mathrm{cm}$ quatro quadrículas contíguas de dimensỏes varitiveis $(\mathrm{Cl}, \mathrm{C} 2$, e $\mathrm{C4})$, alcançou os $12 \mathrm{~m}^{2}$. A camada irqueológica timha a espessum de $40 \mathrm{~cm}$ e fol escavada em níveis artificiais de $10 \mathrm{~cm}$ cada um, contando-se, portanto, quatro destes níveis.

Os sedimentos finos e arenosos resultantes da decomposiça do arenito continham muitos fragmentos e blocos ainda năo inteiramente decompostos, os maiores medindo em média $70 \times 50 \times 20 \mathrm{~cm}$

Nos niveis superiores, onde se achavam bem secos, es sedimentos eram muito friáveis e apresentavam coloração acinzentada que se tornava rosada em direçióo aos niveis inferiores. O solo estéril subjacente é avermelhado e friàvel, de arenito em decomposiçăo e se inclina para baixo no ângulo sul como toda a camada arqueológica. ${ }^{2}$.

\section{Material arqueológico}

O material litico se concentrava principalmente contra a patede do fundo do abrigo ca ceraimica na direção da entrada.

Os instrumentos líticos eram todos lascados. A mstéria-prima utilizada foi o basalto, o quartzo ou o arenito metamorfizado. Foi possível identificar os seguintes instrumentos:

a) Vinte pontas-de-projétill pedunculadas e com aletas.

b) Algumas pontas lanceoladas.

c) Um grande biface alongado.

d) Um raspedor.

e) Lascas retocadas.

Além đestes, existem:

f) Alguns núcleos e grande quantidade de restos de lascamento.

8) Seixos com ou sem sinais de utilizaç̧̌̆.

Foram encontrados cineo fragmentos de ceramica da tradiçăo Tupiguarani nos dois primeiros niveis, isto é, até os $20 \mathrm{~cm}$ de profundidade. Por suas dimensסes, pertenciam a Vasilhas pequenas.

Nos primeiros niveis se observou também a penetraçấo de pequenos fragmentos Inetálicos oriundos da ferraria que ocupou o abrigo. 
As ûnicas estruturas observadas foram: (1) indicio de fogueira localizado contra a parede do fundo, no lado direito da entrada, contendo carvĩo e cinzas e (2) alguns blocos de arenito ao que parece empilhados durante a ocupação.

\section{Datapĩo}

Temos uma única dataçঙ̆o radiccarbônica:

$$
905 \pm 95 \text { a.P.: A.D. } 950-1140 \quad(30-40 \mathrm{~cm}) .(\mathrm{SI}-1196)
$$

Esta đata deve corresponder ao período pré-cerámiço da ocupaçāo, poiss somente foit encontrada cerâmica até $0 s 20 \mathrm{~cm}$ de profundidade.

\section{RS-SM-7: Abrigo da Pedra Grande}

O abriggo da Pedra Grande está formado por um bloco de arenito de enormes dimensces, solevantado e orientado NNO-SSE, que mede $86,5 \mathrm{~m}$ de comprimento, $9 \mathrm{~m}$ de espessura màxima e $8,5 \mathrm{~m}$ de altura máxima no centro. $\mathrm{O}$ bloco se encontra em um pequeno vale situado a $160 \mathrm{~m}$ s.n.m., cercado de elevaçóes e aberto para o sul, por onde 6 . drenado por um afluente đo arroio Ribeirāo e đo rio Toropi, subafluente do lbicuí que se dirige ao rio Uruguai.

O bloco se inclina para ENE e sua face por este lado é um pouco concava, formando um abrigo muito largo e pouco profundo, que mede $70 \mathrm{~m}$ de comprimento por somente $2 \mathrm{~m}$ de profundidade e $8 \mathrm{~m}$ de altura máxima. ${ }^{30}$

Os petroglifos se acham concentrados na zona central do abrigo, onde este aptesenta maior profundjdade. Formam um painel que mede $24 \mathrm{~m}$ de comprimento e aleança mais de $2 \mathrm{~m}$ de altura. Dois outros conjuntos muito menores se encontram muito distanciados nas duas extremidades do bloco onde não há praticamente mais nenhuma proteção do abrigo (Fig. 6). ${ }^{31}$ 


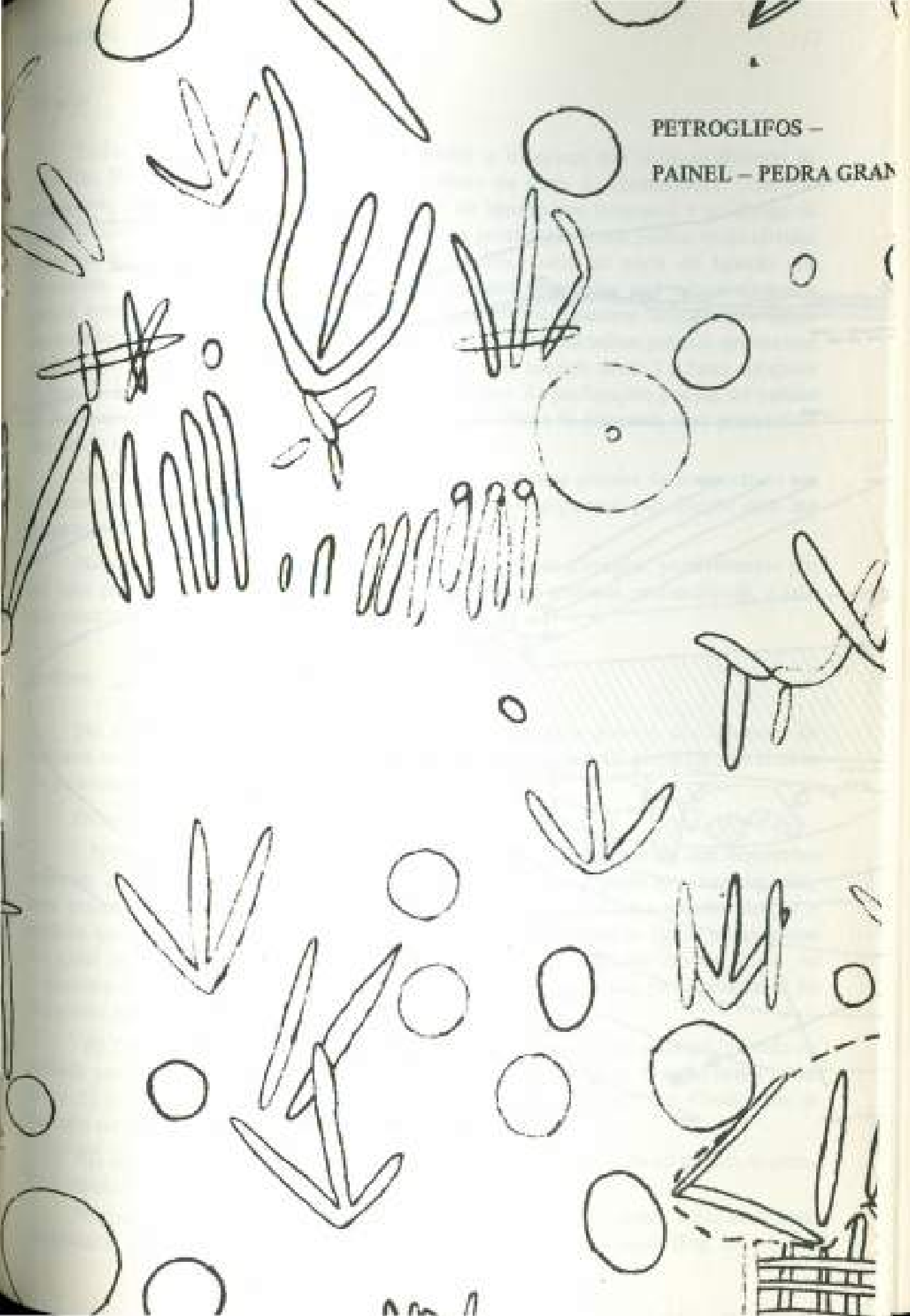





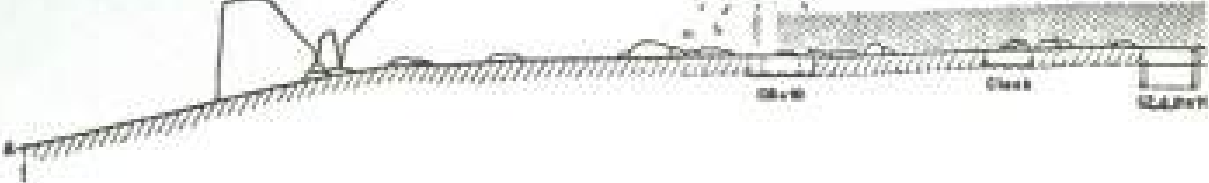

\section{ire com}

petroglifos Af

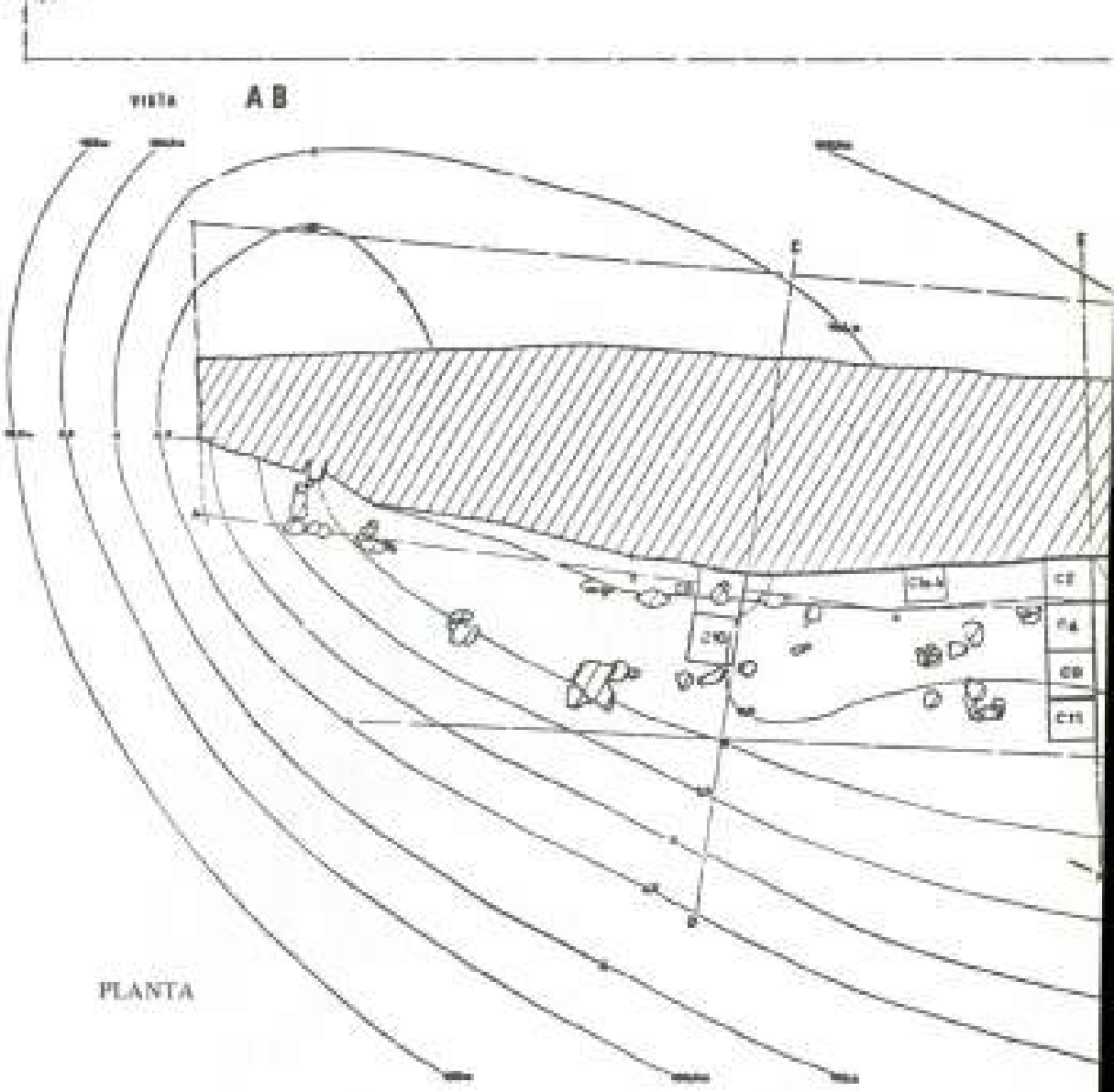




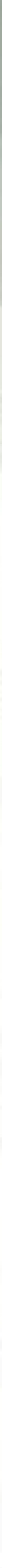




\section{Pitrogilifos....}

\section{Téraica}

Todos os petroglifos foram gravados, porém se observan très técnicas distintas de gravaflo. Uma por picotamento e raspagem, como na gruta de Canhembord. Uma por polinento, como nas grutas de Canhemborá e do lajeado dos Dourados e no abrigo da liah Sétima. Finalmente, as perfuraçōes menores pareco que foram muitas vezes obtidas broqueando a parede com uma ferramenta rotativa, como na gruta do lajeado dos pourados. As técnicas de gravaçắo foram as mesmas observadas nos outros abrigos e grutas, mas as secçōes e profundidades dos sulcos apresentam maiores variaçōes. Os sulcos axecutados por picoteamento e raspagom ș̌̄o largos e rasos. Os sulcos polidos apresentam xeçбes em U muito rasas, ou em V muito agadas, que medesn desde $2 \mathrm{a} 3 \mathrm{~mm}$ até quase 2,5emn de largura, com profundidades correspondentes. As perfuraçōes podem ser polidas ou broqueadas e medem desde 2 ou $3 \mathrm{~mm}$ até quase $20 \mathrm{~cm}$ de diametro, com profundidades desde uns 2 ou $3 \mathrm{~mm}$ até quase $15 \mathrm{~cm}$.

Muitas vezes os sulcos ou perfuraçoes apresentam uma pintura de cor preta no seil interior, a qual parece ter sico executada aplicando o pigmento por fricçīo com um fragmento mineral brasdo ou previamente macerado.

$\mathrm{Na}$ parte inferior do painel năo se observa pintura nas gravaçбes, possivelmente por ser esta parte muito lavada pelas chuvas, já que devido i pequena profundidade, o teto nāo censtitul abrigo suficiente.

\section{Motives}

No extremo SSE do painel principal de petroglifos se observa um conjunto de motiwos semelhantes aos da gruta de Canhemborá e, como naquela, gravados pela téenica do picoteamento e raspagem.

Os motiwos principais săo:

I) Depressōes circulares, rasas, rodeadas em parte por quatro ou seis depressós menores que sagerem pegadas de um felino. Algumas destas pegadas se acham isoladas, mas outras est đo alinhadas, formando dois rastros que apresentam a mesma direçāo e sentido que os da gruta de Canhemborá; isto é, começando a mais de $1 \mathrm{~m}$ de altura scima do nível atual do piso do abrigo, sobẹm pela parẹde até mais de $2 m$ de altura. As dimensoes das pegadas são médias, comparadas is de Canhemborí, pois o diảmetro đa ¿epressio central varia entre 6 e $8 \mathrm{~cm}$.

iI) Três sulcos retilineos convergentes ou um sulco curvo, em meia-lua, cortada na mietade pot outro sulco retilinco e vertical, sugerindo pisadas de aves, O sulco maiot mede tatre 12 e $15 \mathrm{~cm}$. Algumas destas pisadas se acham pintadas, outras não. Geralmente se alinham no mesmo sentido e direçäo dos nastros dos felinos.

III) Sulcos circulares cu elipticos com uma perfuração alongada no centro, sagerinto simbolos sexuais femininos.

Nestas gravaçōes nâo se observam restos de pintura e parecem estar bem mais Atsigastadas pelo tempo que as gravaçōes dos motivos arrolados a seguir (Fig. 5). 
A maior parte de painel principal se compōe de uma grande quantidade de perfuraçōes de dimensoles variactas e sulcos predominantemente retilineos, diversamente orientados, que podem estar separados ou combinados eatre si. Os sulcos e as perfuraçōes matores foram executados pela técnica do polimento e as perfuraçós menores foram broqueadas.

Apenas podemos tentar isolar alguns motivos, tais como:

1) Trës, quatro ou cinco sulcos retilineos convergentes, com dimensōes variando desde 6 até $12 \mathrm{~cm}$, sugerindo pisadas de aves. Algumas destas pisadax se encontran pintadas de preto ou cor de chumbo. Näo se alinham formando rastros, porém q̧ase sempre se orientam com os dedos para cima.

2) Sulcos retilineos verticais e paralelos, obliquos ou convergentes, que podem estar ou nāo delimitados ou cortados por outro horizontal. Alguns destes săo muito profundos, aptesentam soç̧ə⿱o em V curvilínea, com as bordas bem nitidas e o fundo cōncawo parecen afiadores ou polidores, por exemplo, de gumes de machados.

3) Suicos retilíneos verticais e paralelos, cortados por outros horizontais, formando grades que podem ser abertas ou delimitadas por outros sulcos.

4) Sulcos retilineos, mais compridos, com outros menotes, paralelos, alinhados obliquamente de un e de outro lado ou somente de um lado, lembrando o desenbo esquematizado de espinhas de peixe ou empltumaduras de flechas. estrela.

5) Sulcos retilíneos entrecruzados sobre uma perfuração central, sugerindo una

6) Perfuraçōes circulares com pequenos sulcos irradiando da sua periferia, sugerindo a imagem do sol.

7) Sulcos curvilineos desenhando a forma de um $\mathbf{U}$.

8) Perfuraçōes cilindticas de dimensōes variáveis, alinhadas, is vezes desenhando figuras lineares quebrabas.

9) Perfuraçôes cilindricas agrupadas, ds vezes delimitadas por sulcos, como, por exemplo, desenhando uma figura losangular.

Existe também grande quantidade de perfuraçôes de origem natural, resultantes d: erosão alveolar do arenito da parede $c$ łs vezes é difícil distingui-las das perfuraçoes artificiais. Além disso, muitas foram modificadas pelo acréscimo de sulcos ou aprofun dadas de alguma forma.

Observe que as perfuraçöes circulares ou cilifidricas de maiores dimensōes ef sulcos retilíneos verticais mais profundos, que poderiam ser afiadores, se concentrart principalmente ta parte baixa da parede. As perfuraçöes, muitas vezes, em vez de serert perpendiculares à parede, se inclinam para baixo.

Ê muito comum a sobreposiçăo de motivos distintos: principalmente a de perfurt p̧óes menores no interior de outras perfuraçzes maiores ou de sulcos, ou a de perfuraçito maiores no interior das grades formadas pelos sulcos. 
Os círculos e elipses descritos como motivo III, gravados por picoteamento e raspagem, em geral se acham também parcialmente obliterados pela superposiçáo de graviras de alguns dos motivos arrolados acima como $1-8$, executadas por polimento. fintre estes últimos se observa também a substitukiçlo parcial de gavaçōes já quase obliteradas pelo tempo, por outras novas. Isto ocorre principalmente quando a superfície sobre a qual foi gnivada un motivo desapareceu pela esfoliaçâo de uma fina camada do arenito. Entåo foi gravado um outro motivo, quase sempre de menores dimensóes, sobre a nova superficic criada na cicatriz.

Este fato possibilitou o estabelecimento de uma cronologia relativa das gravaçōes, pois se observa que:

a) os circulos e elipses gravados por picoteamento e raspagem foram obliterados por antivos gravados por polimento; $c$

b) de cada vez que esfoliaram partes destas gravaçoes por polimento, executadas com sulcos profundos e largos, muitas vezes com pigmento preto no seu interior, sempre foram substituidas por outras de menores dimensōes, principalmente pisadas de ave com azis de trës dedos, gravadas com sulcos mais estreitos e rasos e que não apresentam restos de pinturia.

Temos, portanto, estabelecida uma diacronia entre o que poderiamos chamar de três estilos diferentes, caracterizados pelas diferentes tícnicas, motivos e dimensōes das gृavuras.

Como as novas gravaçoes só foram executadas depois da esfoliaçato da superfície onde estavam as antigas, devem estar separadas por bastante tempo.

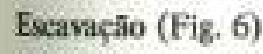

Em 1971 se escavaram onze quadriculas, cada uma medindo em geral $4 \mathrm{~m}^{2}$, e somando uma firea total de cerca de $44 \mathrm{~m}^{2}$. A escavação se processou em níveis artificiais te $10 \mathrm{~m}$ de espessura.

$\mathrm{Na}$ face do blcoo que forma abrigo foram escavadas sete quadriculas, Quatro quadriculas contiguas formando uma trincheira perpendicular à parede do fundo $\left(\mathrm{C}_{2}, \mathrm{C} 4\right.$, C e C11) e uma quadricula isolada (C1) foram escavadas no centro do painel principal dos petroglifos.

Duas quadriculas contiguas formaram outra trincheira, também perpendicular à parede do fundo, no extremo esquerdo do painel $(\mathrm{C} 8, \mathrm{ClO})$ e mais uma quadricula isolada foi escavada alguns metros além do extremo direito do mesmo painel (C3). Trếs quadriculas em parte contíguas foram escavadas na fuce oposta do abrigo, mais próximas do extremo NNO do bloco (C5, C6, C7).

As oito quadrículas escavadas dentro do abrigo revelaram como o desmoronamento th aba do teto formou um muro paralelo ao fundo, constituido de grandes blocos e lajes que medem desde mais ou menos $70 \times 80 \times 80 \mathrm{~cm}$ até $4 \times 2 \times 2 \mathrm{~m}$. Este muro tem o seu topo afastado uns $4 \mathrm{~m}$ do fundo e os maiores blocos ainda sobressaem mais de $1 \mathrm{~m}$ acima do aivel atuad do solo. Como os depósitos preenchem os espaços existentes entre o referido 
maro e a parede do fundo do abrigo e entre os próprios biocos que formam o muro, siaz espessura é muito variaivel. A camada arqueológica atinge até $140 \mathrm{~cm}$ de espessura junto à parede do fundo e diminui para somente uns $50 \mathrm{~cm}$ de espessura para o exterior da parte abrigada pela aba do teto, contando-se, portanto, desde 5 at 14 dos niveis artificiais de $10 \mathrm{~cm}$ cada um, por quadricula.

Os sedimentos finos e arenosos resultantes da decomposiçăo do arenito, continham muitos fragmentos $\mathrm{c}$ blocos ainds năo inteiramente decompostos. A primeira camada de 4 ou $5 \mathrm{~cm}$ de espessura, é seca e friável e apresenta coloração rosea, todo o restante tem coloraçđ̂o escura: cinzenta ou marrom; e se mantém quase sempre seca e friável sté a base. quando no interior do abrigo, sendo úmida c compacta no seu exterior.

A rocha de base é o arenito em decomposiçă̌ ou um sedimento arenoso estéril de cor amarelada, mais ou mencs compacto.

Observou-se que a maior parte dos desmoronamentos ocorreu antes da ocupaçia, portanto a deposiçấo posterior, isto é, a camada arqueológica, encheu o espaço entre o muro e a parede do fundo, $e$ o piso atual se inclina suavemente para fora do abrigo.

A base do bloco se encontra elevada uns $7 \mathrm{~m}$ acima do nível do vale, mas o seu talude é bastante suave por ambas as faces.

\section{Material arqueológico}

Nas quadrículas escavadas sob o abrigo, a indústria lítica está constituida de instrumentos lascados, polidos e picoteados. A matéria-prima utilizada foi o basalto, 0 arenito metamorfizado $\mathrm{e}$, em menor quantidade, o quartzo, a comalina ete. $\mathrm{O}$ material lítico nj్ é nem abundante nem caracteristico, encontramos:
a) Choppers.
b) Raspadores.
c) Lascas grandes com retoques periféricos.
d) Duas pontas lanceoladas.
c) Uma plaina.
f) A extremidade proximal de um biface e um instrumento bifacial.
g) Uma lasea retocads como faca.
h) Uma ponta-de-projétil pedunculada e com aletas,
i) Batedores e quebra-coquinhos com depressöes.
j) Um polidor plano-côncavo.
k) Um disco de arenito.
1) Um polidor de arenito.
m) Um machado cilíndrico picoteado, com o gume polido e um sulco eshoçado nt extremidade proximal.

Finalmente havia:

n) Alguns núcleos e muitos restos de lascamento.

o) Lascas com ou sem sinajs de utilização. 


\section{Pesingalifos....}

Foram encontrados fragmentos de cerảmica da tradiçăo Tupiguarani na superficie e en algumas quadriculas até $60 \mathrm{~cm}$ de profundidade.

Os instrumentos, núcleos e lascas majores se concentravam na parte externa do mare de blocos caídos e os restos de lascamento na parte interna, como se os ocupantes tivessem quebrado os blocos de matéria-prima no exterior e jdo retocar os instrumentos no interior, junto à parede do fundo. Todo o material arqueológico se rarefazia para fora do abrigo.

Observaram-se alguns indicios de foguciras que somente continham carvoes e cinzas. Existem poucos residuos de alimentaçaio: ossos de pequenos animais, principalmente manaiferos, carapaças de caracóis $\mathrm{e}$ sementes de palmáceas carbonizadas.

Em duas prospeçōes, executadas em 1969 na parte posterior do abrigo, se identificou um extenso sitio com cerâmica đa tradiçāo Tupiguarani, no qual se observaram uns vinte locais onde se concentravam na superficic do solo fragmentos de cerärnica $e$ instrumentos líticos. Estas concentraçôes indicariam vestígios de habitaçōes de planta circular, medindo desde 10 até $50 \mathrm{~m}$ de diàmetro, sendo mais comuns as de entre 20 e $50 \mathrm{~m}$ de diàmetro. Uma aglomeraçăo de 10 habitaçôes se encontra a oeste do abrigo, Outra com sete habitaçdes está afastada $300 \mathrm{~m}$ para noroeste. Mais quatro habitaçóes boladas se encontram espallhadas ao redot, a 200 e $500 \mathrm{~m}$ ao sul c a $700 \mathrm{~m}$ a oeste.

O material lítico superficial se compôe de duas dúzias de discos biçonvexos de arenito, picoteados ou polidos (lentilhas), um machado discotdal com gume periférico (itaiç) e uma cunha de ferro encontrada nas proximidades.

Em 1971, se escavaram também três quadriculas, em parte contigua, em dẹpositos acumulados contra a parte posterior do bloco do abrigo. A escavaça foi executada em niveis artificiais de $7 \mathrm{~cm}$. A camada arqueológica tinha a espessura de $50 \mathrm{~cm}$ e estava constituida de solo arenoso-argiloso, hümico, de coloraçs̃o muito escura, úmido porém fïivel, contendo ainda grande quantidade de fragmentos de arenito. $O$ substrato estéril tem a mesma composição que o das quadriculas escavadas dentro do abrigo. 0 material arqueológico obtido foi:

a) Grande quantidade de fragmentos de cerámica da messna tradiçăo Tupiguarani, como os que foram recolhidos superficialmente e escavados até os $60 \mathrm{~cm}$ nas quadriculas executadas dentro do abrigo.

b) Fragmentos de cerimica da tradiçs̃o europétia, alguns importados, incluindo majólica, mas a masioria provaveimente fabricados localmente.

c) Ossos e dentes de un animal de grande porte - cavalar ou vacum.

Nos arredores foram encontradas, por moradores da localidade, trē̉ urnas funerárias de dimensōes médias. Uma delas possui estranhas alças ou asas colocadas pelo lado Intemo em vez de externamente o outra continha contas cilindricas de vidro azal e beanco.

Temos trêt dataçôes radiocarbònicas para as quadriculas escavàlas sob o abrigo:

$$
\begin{array}{rrr}
605 \pm 40 \text { a.P. A.D. } 1305-1385(C 2,30-40 \mathrm{~cm}) & (\mathrm{SI}-1002) \\
800 \pm 40 \text { a.P. A.D. } 1110-1190(\mathrm{C} 2,60-70 \mathrm{~cm}) & (\mathrm{SI}-1003) \\
2795 \pm 55 \text { a.P. } 900-790 \text { a.C. } \quad(\mathrm{C} 10,70-80 \mathrm{~cm}) & (\mathrm{SI}-1004)
\end{array}
$$


Como na gruta de Canhemborá, estas dataçōes, sepandas por vinte e trềs séculos,

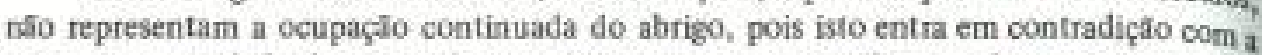
pequena quantidade de material arqueologico e sua estratigrafia, mas devem corresponder a trés momentos sucessiwos $\mathrm{e}$ distintos de coupaçăo.

Nos niveis correspondentes as primeiro momento de ocupaçăo, datados ea. $900-790$ a.C. (70-80cm) nấ existem pontas-de-projétil, porém nos niveis correspondentes ao segundo momento de ocupaç5̃o, datados ca. A.D. $1110-1190(60-70 \mathrm{~cm})$, aparece a ponta-de-projétil pedunoulada e com aletas (CI0) e o machado polido no gume (C11).

Em alguns casos, fragmentos de cerrâmica da tradiçăo Tupiguarani foram encontrados atê $60 \mathrm{~cm}$ de profundidade, mas é mais provivel que se telacionem com um terceito momento de ocupação datado ca. A.D. 1305-1385 (30-40cm).

Além disso, o sítio cerămico superficial foi identificado como o local da Reduçäa de São José, o que permite datj-lo A.D. 1633-1637.3 No entanto, nIlo existe entre os petroglifos nenhum motivo que se possa relacionar com as atividades missionárias.

A conexî́o entre os petroglifos e a camada arqueológica se fez da seguinte maneira:

No nivel $70-80 \mathrm{~cm}$ da quadricula 2 (C2) se encontrou um fragmento plano de arenito, esfoliado da parede do abrigo, apresentando parte de um petroglifo cujo restante ainda é visivel in situ acima da quadricula. Portanto, alguns dos petroglifos ainda sño mais antigos do que esta primeira ocupaçño datada ca. $900-790$ a.C.

Mais acima, na mesma quadrictala, no nivel $40-50 \mathrm{~cm}$ se encontrou outro fragmento esfoliado da parede à major altura do que o anterior e se observou que na cicatriz deixada pela sua queda foram executadas algumas perfuraçōes. Portanto, en época posterior a esta ocupaçăo, datada ca. A.D. 1200-1300, por comparaçắo com as dataçốes radiocarbónieas dos niveis inferior e superior, ainda se executavam petroglifos.

Desta mancira fica demonstrada pelo menos a contemporaneidade das camadas arqueológicas com os petroglifos. Pode-se aftrmar também que os petroglifos hoje existentes formam um agregado que foi sendo aumentado em vários momentos sacessivos desde antes de ca. 900 a.C. até depois de ca. A.D.1300, portanto ao Jongo de dois mall e duzentos ou dois mil e quatrocentos anos.

\section{Sintese}

É característica a situaçấo topográfica dos abrigos e grutas, naturalmente escavados em paredōes de asenito, abrindo para a várzea de um grande rio, o Jacuí, com rampus muito fortes nos taludes de acesso, com exceçăo do abrigo da Pedra Grande que se abre para um pequeno vale, drenado por um sabafluente do rio Toropi, e cujo acesso te muito suave por ambas as faces. ${ }^{33}$

Todos os abrigos e grutas foram ocupados pelo homem. A area efetivanenta protegida pelo teto é sempre pequena, mas antigamente $c s$ paredões estavam cercados de árwores de grande porte cuja folhagem protegia a entrada das intemperies; mesmo assint. devido a pequena área disponivel para a ocupaçăo hamana, esta deve ter se resurnido sempre a grupos muito pequenos, compostos de umas poucas pessoas de cada vez. A 
çupą̧̃o começou sempre quando o piso ainda estava atravancado de grandes blocos e bjes despreendidos do teto e das paredes. Ainda que o espaço disponivel fosse muito pequeno, as ocupantes viveram no meió destes blocos de 0,40 a $1,80 \mathrm{~m}$ de altura, ut 1 izando-os como móvels ou anteparos para as suas fogueiras.

O fato de que as graraçōes tenham sido executadas até o teto nas grutas de Canhemborá e do lajeado dos Dourados, a quase $3 \mathrm{~m}$ de altura e até um pouco mais de $2 \mathrm{~m}$ nas puredes dos abrigos - medindo-se desde o nivel atual do piso-sugere a utilizaçăo de escadas ou andaimes para a sua execuçẫo.

\section{IN - SEQÜENCIA CRONOLÓGICA DAS CAMADAS ARQUEOLOGICAS E SEU CONIEODDO: LITICO E CERÁMICO}

O conjunto das dataçôes absolutas, radiocarbónicas e num caso históricas, que possuimos para as csmadas arqueolbgicas dos abrigos da linha Sétima e da Pedra Grande e da gruta de Canhemborí, está representado a seguir, com as datas na sua ordem natural e as camadas a que pertencem interdipitadas estratigraficamente.

\begin{tabular}{|c|c|c|c|c|}
\hline $\begin{array}{l}\text { METODO DE } \\
\text { DATAÇÄO }\end{array}$ & $\begin{array}{l}\text { DATAÇĀo } \\
\text { (1- siggma) }\end{array}$ & $\begin{array}{l}\text { NOMERO DE } \\
\text { LABORATOKRIO }\end{array}$ & LOCAL & $\begin{array}{c}\text { POSIÇĀ̃ } \\
\text { ESTRATIGRÁFICA }\end{array}$ \\
\hline $\begin{array}{l}\text { Histórico } \\
\text { Cl4 }\end{array}$ & $\begin{array}{r}\text { A.D. } 1633-1637 \\
\text { A.D. } 1305-1385 \\
\cdot 1245-1375\end{array}$ & (S1-1002) & $\begin{array}{l}\text { Pedra Grande } \\
\text { Pedra Grande }\end{array}$ & $\begin{array}{c}\text { Superficie } \\
\mathrm{C2}, 30-40 \mathrm{~cm}\end{array}$ \\
\hline $\mathrm{C} 14$ & $\begin{array}{r}\text { A.D. } 1110-1190 \\
-1145-1225\end{array}$ & (SI-1003) & Pedra Grande & $\mathrm{C} 2.60 .70 \mathrm{~cm}$ \\
\hline $\mathrm{Cl} 4$ & $\begin{array}{r}\text { AD. } 950-1140 \\
965-1155\end{array}$ & (SL-1196) & linha Sêttima & $30.40 \mathrm{~cm}$ \\
\hline $\mathrm{Cl} 4$ & $\begin{array}{r}\text { A.D. } 750.820 \\
\times \quad 765-855\end{array}$ & (SI-1000) & Canhembora & $\mathrm{C} 5,40.50 \mathrm{~cm}$ \\
\hline $\mathrm{Cl} 4$ & $\begin{array}{r}900-790 \mathrm{a} . \mathrm{C} \\
-1075-965 \mathrm{a} . \mathrm{C}\end{array}$ & (SI-1004) & Pedra Grande & $\mathrm{C} 10,70-80 \mathrm{~m}$ \\
\hline $\mathrm{Cl} 4$ & $\begin{array}{l}1080.910 \text { a.C. } \\
-1345-1135 \text { a.C. }\end{array}$ & (SI-1001) & Canhemborá & $\mathrm{C} 5,60.70 \mathrm{~cm}$ \\
\hline
\end{tabular}

C14:Dataçōes radiocarbònicas exuctutadas polo Radiarion Biofogy Laboratory da Smithoonian Instiation

Correçäo MASCA, Applied Science Center for Archaplogy" (Ralph. Michael \& Han, 1973).

0 gráfico seguinte (Fig. 7 ) demonstra de maneira mais clara as relaçōes existentes entre as dataçoes radiocarbonicas e a estratigrafia dos abrigos $e$ grutas. As barras centrais pretas indicam as dataçōes de $\mathrm{Cl} 4 \mathrm{e}$ as brancas, as suas correçōes MASCA, sempre com o fesvio padrīo estatístico usual de 1 sigma. As escalas laterais representan a estratigrafia Gs diversas quadriculas condensadas numa única coluna estratigráfica para cada sittio. 


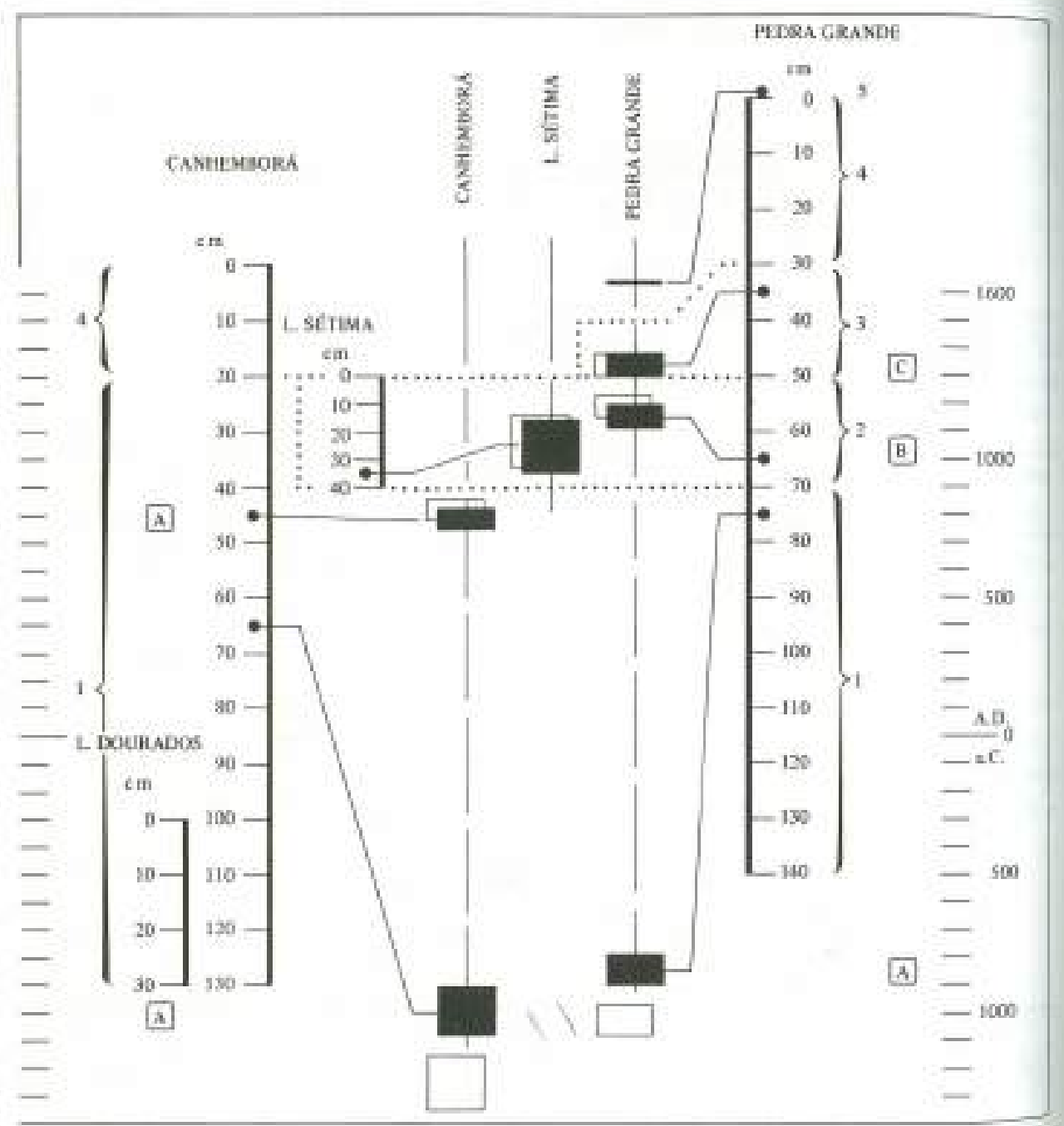


As linhas relacionam as dataçōes a posiç̧o estratigráfica das amostras datadas.

A comparaçto do material arqueológico: lítico e ceraimico, com as dataçōes radioarbonicas e a sua estratigrafia, sugere que existiram cinco momentos distintos e sucessivos de ocupaçắo humana dos abrigos e grutas, cada um deles caracterizzdo pelo seu contexto analitico, que podem ser diacronizados como segue.

As quatro primeiras ocupaçốes humanas sfo pré-históricas: duas delas pró-cerâmicas, seguidas por uma que se poderia chamar pós-cerâmica e outra cerámica; e a quinta jả é histórica, correspondeado ao momento do contato entre indigenas e missionários no século XVII.

\section{1) Un momento de ocupaçẫo pré-cerảimica sem pontas-de-projétil}

Material arqueológico: Caracterizadio principalmente pelos bifaces grandes e alongados, os machados polidos no gume, as mós ou trituradores planos feitos por picoteamento e os fragmentos de mineral corante aguçados nas extremidades, provavelmente usados para pigmentat e polit as gravaçôes.

Sítios e posição estratigrifica: Na gruta de Canhemborá, como nāo se observam mudanças significativas no material arqueológico, se pode atribuir, a mesma tradiçâo cultural, praticamente toda a espessura das camadas depositadas no seu interior, exceto talvez as primeiros $20 \mathrm{~cm}$ onde aparecem fragmentos de cerámics da tradiçă̌o Tupiguarani. Mesmo assim estes podem ter penetrado desde a superficie e indubitaveimente se relacionam com um outro momento de ocupaçio posterior da gruta de que falaremos adiante.

As duas dataçổes radiocarbônicas: $1080-910$ a.C. (C5, 60-70cm) (SI-1001) A.D. $750-820(\mathrm{CS}, 40-50 \mathrm{~cm})$ (SI-1000), apesar de estratigraficamente serem quase contiguas na mesma quadricula, se acham separadat por um hiato de mil seiscentos e sessenta anos, o que $\$ 5$ pode indicar duas ocupaçōes sucessivas por portadotes da mesma tradiçăo cultural, xeparadas por este espaço de tempo.

No abrigo da Pedra Grande há maito pouco material característico, no entanto, a usència de pontas-de-projétil e a dataçతo: $900-790$ s.C. (C10, 70-80cm) (SI-1004) que se pode correlacionar com a $1080-900$ i C. na gruta de Canhemborá, permitem atribuir os níveis $70-140 \mathrm{~cm}$ à mesma ocupação.

Na gruta do lajeado dos Dourados ocorreu apenas uma úntica ocupaçă亍o e de pouca duraçäo, atestada pela pequeria quantidade de material e a pouca espessura dos sedimen$\cos (\mathbf{C} 1,0-30 \mathrm{~cm})$. Não há datação radiocarbùnica, mas a presença do material característico, principalmente os grandes bifaces alongados, permite atribuir a sua única ocupaço ios portadores da mesma tradição cultural, situando-a correlativamente no tempo com a oupaç̧̌̉o dos outros abrigos e grutas.

Posiçáo temporal: $\mathrm{A}$ estratigrafia da gruta de Canhemborá indica que este primeiro momento de ocupação se iniciou antes de 1100 a.C., pois abaixo do nível datado (CS, $60.70 \mathrm{~cm})$ se encontra ainda uma camada de mais $60 \mathrm{~cm}$ de sedimertos.

O mesmo raciocínio naío se pode aplicar a Pedra Grande, pois o nivel datado (C10, $7(-80 \mathrm{~cm})$ é praticamente o tittimo na major parte das quadriculas, pois a camada 
arqueológica somente desce até $140 \mathrm{~cm}$ de profundidade conira a parede do fundo do abrigo, no estreito espaço entre esta e o maro formado pelo desmoronamento da aba do teto que nẫo podia ser utilizado diretamente durante a ocupaçẫo humana.

No abrigo da Pedra Grande ocorreu provavelmente um so momento de ocupacto que pode ser datado $(\mathrm{CIO}, 70-80 \mathrm{~cm}$ (SI-1004), mas na grata de Canhembord, houve una segunda ocupaçăo, defassda cerca de 1600-1700 anos da primeita. Como na mesnas quadrícula existem ainda mais 20 au $30 \mathrm{~cm}$ de deposiçōes de sedimentos acima do segundo nivel datado $(\mathrm{CS}, 40-50 \mathrm{~cm})$, o final deste primeiro momento de ocupaçăo dos abrigos e grutas pode ser um pouco posterior a A.D. 750 - 820 (SI-1000).

Antes ca. 1100 a.C. a depois de A.D. 800.

A tradiçăo cultural representadia pode muito bem ter existido na área por mil e novecentos anos, ocujando em diversas ocasióes distintas os abrigos e grutas.

\section{2) Um momento de ocupaçáo pré-cerámico com pontas-de-projétil}

Material arqueologico: Caracterizado principalmente pelas pontas-de-projétil pedunculadas e com aletas, as pontas-de-projétil lanceoladas, as facas bifaciais sobre lascas, e os machados cllíndricos picoteados, polidos no gume e com sulcos esboçados: mas continuam os grandes bifaces alongados. Corresponde ao contexto analitico da fase Rio Pardinho no seu momento pré-cerảmico. A fase Rio Pardinho, da qual falaremos adiante nas comparaçōes do material arqueológico, é característica da encosta do planalto meridional, a leste do vale do rio Jacui ${ }^{33}$

Sitios e posiça estratigráfica: No abrigo da linha Sétima the foram atribuidos os

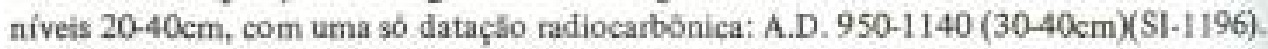

No abrigo da Pedra Grande existe uma dataçấo correlativa: A.D. 1110-1190 (C2, $60-70 \mathrm{~cm})(\mathrm{Sl}-1003)$ e se observa o mesmo material caracteristico, embora em menor quantidade, de maneira que os niveis $50.70 \mathrm{~cm}$ ou $60.70 \mathrm{~cm}$ se podem atribuir à mesma ocupação.

O nível seguinte, mas em outra quadricula $(\mathrm{Cl} 0,70-80 \mathrm{~m})$, apresenta ura dataço muito distinta: $900-790$ a.C. (SI-1004), de onde se deduz que a grata fol desocupada durante cerca de mil e novecentos anos. No entanto, à diferença do que ocorreu na gruta de Canhemborí, não foi reocupada por portadores da mesma tradiçăo cultural mas pelos de uma outra, a fase Rio Pardinho, que poderia também corresponder a um momento mais recente da mesma, o que, apesar de possível, nđo tem comprovaçđo.

Nas grutas de Canhemborá e do lajeado dos Dourados nâo se observa o material arqueologico característico deste momento e do seguinte, principalmente as pontas. deprojétil pedunculadas e com aletas, nem temos dataçós correlativas, de onde $x$ deprende que nso foram ocupadas pelos portadores desta traduçáo cultural.

Posiçāe temporal: Devido is duas dataçōes radiocarbóniças, se pode situar com bastante clareza entre ca. A.D. 950 e 1200. 
3) Um momento de ocupaçlo com pontas-de-projétil e cerimica da tradiçấo Tupiguarani (fase Rio Pardinho pós-ceraimica)

Material arqueológico: Caracterizado pelas mesmas pontas-de-projétil pedunculadas e com aletas ou lanceoladas do momento anterior, mas, destas vez, acompanhadas de fragmentos de cerämica da tradiçầo Tupiguarani. ${ }^{3 b}$

O nủmero de fragmentos de ceràmica é muito pequeno (5 ou 6) mesmo em relaçâo ao número também pequeno de instrumentos líticos. Como os sítios típicos dos portadoses da tradiçāo cerámica Tupiguarani apresentam sempre muito maior quantidade de fragmentos, desde algumas centenas ate milhares e, por outro lado, neles nj̧o existem pontas-de-projétal líticas, fica excluida a possibilidade de que esta ocupaçăo corresponda diretamente acos portadores daquela tradipāo.

A pequena quantidade de fragmentos de cerámica e sua posiçấo estratigráfica no abrigo da linha Sétima, sugere que as vasilhas foram adquiridas pelo mesmo grupo pể-ceràmico por meio de trocas efeluadas com os portadores da tradiçāo cerầnica Tupiguanui, representando, portanto, uma situaçīo de contato cultural da categoria A, tipo 1 (A.1) segundo a classificaçðo de G. Willey e D. W. Lathrap st

O mesmo processo parece ter ocorrido na fuse Rio Pardinho que possuí muitos sitios sem ceràmica e alguns outros com uma proporçio mais ou menos semelhante de fragmentos de cerámica da tradiçto Tupiguanani. Portanto o material arqueológico, nos momentos de ocupaçio 2 e 3, corresponde ao contexto anal fitioo da fase Rio Pardinho em seus momentos pré e pós-cerâmico, isto é, antes e depois do início đa aquisiça de ceralmica da tradiçăo Tupiguarani por meio de trocas. ${ }^{2+}$

Sítios e posiçio estratigráfica: No abrigo da linha Sétima lhe foram atribuídos os niveis $0-20 \mathrm{~cm}$, quando aparecem fragmentos de cerámica no mesmo contexto dos níveis inferiores datados A.D. 950-1140(30-40cm) (SI-1 196).

No abrigo da Pedra Grande há uma dataça posterior: A.D. 1305-1385 (C2, $30-40 \mathrm{~cm})(\mathrm{SI}-1002)$ que possivelmente se correlaciona à mesma ocupação, no entanto é mais dificil decidir se representa a fase Rio Pardinho pré ou pos-cerámica, devido à presença ou da penetraçĩo de fragmentos de ceràmica, em algumas quadriculas até $60 \mathrm{~cm}$ de profundidade.

Posiçào temporal: Com a maior probabilidade é posterior a A.D. 1200, estendendo-se talvez até ca. A.D. 1400.

4) Um moniento de ocupaçăo com ceraimica da tradiçấo Tupizuarani

Material arqueologico, sitios e posiçío estratigráfica: Caracterizado pela presença de fragmentos de ceriimica desta tradiçs̃o dos niveis superiores de algumas das quadriculas du gruta de Canhemborí $(0-20 \mathrm{~cm})$ e do abrigo da Pedra Grande (0-60 cmi).

As caracteristicas da cerâmica a relacionam com a fase Vacacai. O inicio desta fase É calculado, em comparaęóes com outras da mesma dreas, como se situando ca. A. D. 1100 , 
mas sua penetraça na escarpa do pianalto deve ter levado algum tempo, de maneira que, ao menos no abrigo da Pedra Grande, onde a ocupaçăo anterior pelos portadores da fase Rio Pardinho teria se prolongado até ca. A.D. 1400 , o injécio da ocupaçăo pelos portado. res da cerimica da fase Vacacal deve ser datado como posterior a esta ulltima data.

Os indígenas da ärea, denominados Tapes pelos cronistas, foram reunidos aas Reduçōes pelos missionários jesuítas espanhóis entre A.D. 1627 e 1641, đe maneira que este periodo mareh, na maior parte dos casos, of final da fase Vacacaf. ${ }^{3}$ ?

Posiçẫo temperal : ca. A.D. $1400-1627 / 41$.

5) Redução de São José. Um momento de ocupação com ceràmica de transiçāo entre a tradiç̣̂o Tupiguarani e a européia (fase Keduçōes)

O grande sitio cerimico superficial situado atrás do abrigo da Pedra Grande, foi identifieado como tendo sido o local da Reduçāo de São José, ocupada A.D. 1633-1637. . $^{\text {V }}$

Resumindo es cinco momentos sucessivos de ocupaçđo humana dos abrigos e grutas, temos:

1) Pré-cerämico sem pontas-de-projétil:

Grutas de Canhemborá e do lajeado dos Dourados e abrigo da Pedra Grande.

Antes de ca. 1100 a.C. atẻ depois de ca. A.D. 800.

2) Fase Rio Pardinho pré-cerảmica:

Abrigos da linha Sétima e da Pedra Grande.

Ca. A.D. $900-1200$.

3) Fase Rio Pardinho pós-cerimica:

Abrigos da linha Sétima e da Pedra Grande.

Ca. A.D. $1200-1400$.

4) Tradiçầo ceràmica Tupiguarani, fase Vacacaí:

Abrigo da Pedra Grande e gruta de Canhemborá.

Ca. A.D. $1400-1600$.

5) Redução de São José:

Proximidades da Pedra Grande.

A.D. 1633-1637,

\section{V - SEQUEENCIA CRONOLÓGICA DOS PETROGLIFOS}

A diacronia observada entre as gravaçōes do abrigo da Pedra Grande pode set estendida, por comparação, aos outros abrigos e grutas pesquisados ma mesma ârea. Neri todos os motivos, assim como as suas dimensōes e a técnica de sua execução, puderån sh realidade ser nitidamente classificados em um ou outro dos trè̉s estilos propostos, ms: seguir procuramos indicar quais as caracteristicas mais importantes de cada um. 
Etilo A (Fig. 1 e 2)

Técnica: Predominantemente por picoteamento e raspagem, nu gruta de Canhemborá e da Pedra Grande, talvez por polimento na gruta do lajeado dos Dourados.

Sulcos largos (até $2 \mathrm{~cm}$ de largura) e rảsos (atê $1 \mathrm{~cm}$ de profundidade). Depressoes largas ( 6 a $14 \mathrm{~cm}$ de diàmetro) o rasas ( 5 a $25 \mathrm{~cm}$ de profundidade). Perfuraçōes de diversas dimensóes (desde $5 \mathrm{~mm}$ de diămetro e de profundidade, até $10 \mathrm{~cm}$ de diämetro e $3 \mathrm{~cm}$ de profundidade).

$\mathrm{Na}$ gruta de Canhemborá, os sulcos e depressōes estĩo usualmente preenchidos com pigmento preto, verde, branco, roxo ou marrom.

Motivos: Pegadas de felino e pisadas de ave com trés dedos, que formem rastros subindo pelas paredes, cítculos ou elipses com perfuração ou suloo central (simbolo sexual feminino), sulcos refilineos verticais paralelos (simbolo fálico), sulcos ondulantes (serpente) e meandros.

Dimensōes: Grandes, ex.: pegada de felino de 6 a 8 , ou de 12 a $14 \mathrm{~cm}$ de diámetro na depressão central; pisada de ave: de 12 a $15 \mathrm{~cm}$ de altura.

Sitios onde se encontram: Grutas de Canhemborá e do lajeado dos Dourados e extre* mo esquerdo do painel principal do abrigo da Pedra Grande.

Posição temporal: No abrigo da Pedra Grande alguns motivos deste estilo se encontram debaixo de gravaçōes do estilo seguinte (B).

\section{Estilo B}

Técatica: Predominantemente por polimento, mas as perfuraçōes, ts vezes, pot picoteamento.

Sulcos largos ( $10 \mathrm{a} 15 \mathrm{~mm}$ de largura) e profundos ( 10 a $25 \mathrm{~mm}$ de profundidade) com secçlio em $\mathrm{U}$.

Perfuraçōes menores (desde $5 \mathrm{~mm}$ até $1 \mathrm{~cm}$ de diämetro), mas que podern ser mais profundas (desde $5 \mathrm{~mm}$ até $5 \mathrm{~cm}$ de profundidade) que as do estilo $\mathbf{A}$.

No abrigo da Pedra Grande os sulcos et perfuraçōes podem estar pintados interiormente de preto ou cor de chumbo.

Motivos: Pisadas de ave com trés dedos ou em forms de áncora, năo formando rutros, sulcos curvilíneos em forma de $\mathrm{U}$, sulcos retilíneos verticsis e paralelos alinhados que podem estar ou nāo cortados por um ou mais sulcos horizontais, às vezes formando grades, espinhas de peixe e perfuraçdes, em geral médias e picoteadas, alinhadas, às vezes desenhando figuras lineares, sulcos retilíneos entrecruzados (estrela) e perfuraçōes das quais irradiam sulcos (sol).

Dimensôes: Médias, ex.: pisada de ave: entre 10 e $12 \mathrm{~cm}$ de altura-

Sítios onde se encontram: Abrigos da linhn Sétima e da Pedra Grande, taivez tumbém na gruta do lajeado dos Dourados.

Posiçio temporal: No abrigo da Pedra Grande alguns dos motivos deste estilo se acham debaixo de gravuras do estilo $\mathrm{C}$ e superpostas a gravuras do estilo $\mathrm{A}$. 


\section{Estilo C}

Técnica: Sulcos estreitos ( 2 a 3 mm de largura) e relativamente rasos ( 2 a $3 \mathrm{~mm}$ de profundidade) com seç̧io em $\mathbf{U}$ ou $\mathbf{V}$, executados por polimento.

Sulcos mais largos (até $25 \mathrm{~mm}$ de largura) e mais profundos (até mais de $5 \mathrm{~cm}$ do produndidade) que os do estilo $\mathbf{B}$ com seç̧⿻ em $\mathbf{V}$, curvilínes, e fundo côncavo que parecem aftadores. Perfuraçóes cilíndricas, broqueadas, com pequeno diämetro (de 2 a $5 \mathrm{~mm})$ e pouca profundidade ( 2 a $10 \mathrm{~mm}$ ).

Auséncia de vestigios de pigmento.

Motivos: Em geral os mesmos que săo mais frequentes no estilo B, mas principal. mente: pisadas de ave com trés ou cinco dedos, sulcos retilíneos verticajs e paralelos cortados por outros horizontais, frequentemente formando grades, muitas vezes emoldu. radas por um sulco, perfuraçðes pequenas alinhadas desenhando figuras lineares ou perfurações pequenas agrupadas e molduradas por sulcos.

Dimensōes: Pequenas, ex.; pixadas de ave: entre $6 \mathrm{e} 9 \mathrm{~cm}$ de altura.

Sítio onde se encontra: Abrigo da Pedra Grande.

Posiçáo temporal: No abrigo da Pedra Grande algans motivos deste estilo se superpōem a motivos do estilo $\mathbf{B}$.

E necessário ressalvar que es estilos propostos năo constituem provavelmente manifestaçōes estanques, mas o mais provável é que representem momentos sucessivos de evolução através do tempo da mesma tradição de gravaçōes rupestres.

Resumindo os dados a respeito de (a) lugares onde se observam os trés estilos propostos e (b) superposiçôes que serviram para efetuar a diacronização entre eles, temos:

ESTILO

C

B

A

\section{LOCAL}

- Somente no abrigo da Pedra Grande, superposto a gravaçoes do estilo B.

- No abrigo da Pedra Grande, debaixo de gravaçōes do estilo C e superposto a gravaçōes do estilo A; no abrigo da linha Sétima; talvez também na gruta do lajeado dos Dourados.

- No abrigo da Pedra Grande, debaixo de gravaçōes do estilo B; na gruta de Canhemborá; na gruta do lajeado dos Dourados.

Relacionando uma com as outras, as superposiçồes das gravaçôes características de estilos diferentes, como foram observadas nos diversos abrigos e grutas, é possivel former uma espécio de estratigrafia, utravés da qual, se A se encontra debaixo de B e B debabso de C, podemos concluir que a sequêencia dos três estilos propostos para os petroglifor deve ser, no sentido da passagem de termpo, isto $\mathrm{e}$, do mais antigo para o mais recente:

$$
\mathrm{A} \rightarrow \mathrm{B} \rightarrow \mathrm{C}
$$


Já vimos como as observaçbes feitas no abrigo da Pedra Grande e, em menor escala, na gruta de Canhemborá, demonstram a existéncia de uma contempotaneidade, pelo menos geral, entre os petrogifos nelas gravados e as camadas arqueológicas depositadas no seu interior.

Por outro lado parece perfeitamente lógico o raciocínjo que os ocupantes dos abrigos e grutas, responsáveis pela deposiçalo das camadas arqueológicas no seu interior. tivessens sido também os que gravaram os petroghifos nas suas paredes e teto.

Combinando entre si (a) a sequéncia cronológica relativa construida com os trể estilos propostos para a diacronizaç̃̃o dos petrogifos e (b) os momentos sucessivos de ocupaçāo humana dos abrigos e grutas onde estes estilos se encontram representados; tomo no gráfico(Fie. 7), temos que:

1. As grutas de Canhemborá e do tajeado dos Dourados, onde se encontra somente D estilo A, foram ocupadas somente pot portadores da mesma tradiçăo cultural pré-cerämica, sem ponta-de-projétill.

2. O abrigo da linha Sétima, onde se encontra somente o estilo B, também só fol ocapado por portadores da fase Rio Pardinho, nos seus momentos pré e pós-cerảmico.

3. O abrigo da Pedra Grande, onde se observam os très estilos (A, B e C) fol ocupado sucessivamente pelos portadores das duas tradiçōes culturais acima, sendo que, neste abrigo, a fase Rio Pardinho, provavelmente no seu momento pós-ceràmico, apresenta uma datação mais tardia do que no da linha Sétima: A.D. 1305-1585 (SI-1002). Recordamos então que o estilo C também só se observa neste abrigo.

As diversas coincidéncias espaciais e temporais - pois a ordem de sucessão dos estilos A, B e C também coincide com a das ocupaçöes $(1,2,3)$-sugerem, portanto, o seguinte relacionamento:

estilo A - com a ocupação poé-ceràmica sem pontas-de-projétil nas grutas de Canhemborá e do lajeado dos Dourados e no abrigo da Pedra Grande, entre ca. 1100 a.C.e A.D. 800;

estilo B - com os portadores da fase Rio Pardinho précerámica, nos abrigos da linha Sétima e da Pedra Grande, ca. A.D. 900-1200;

estilo $\mathrm{C}$ - com os portadores da fase Rio Pardinho pós-ceraimica, no abrigo da Pedra Grande, ca. A.D. $1200-1400$.

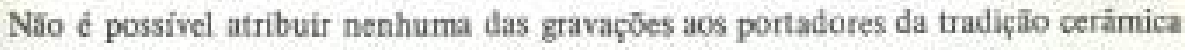
Tupigarani, tanto na gruta de Canhemborá como no abrigo da Pedra Grande, porque em todo o imenso ámbito onde eles se espalharam no leste da América do Sul, jamais apresentaram este tipo de manifestaçäo cultural. Também nẫo se observam entre os petroglifos motivos que pudessem sugerir a intervençäo dos índios da Reduçăo ou dos missionários,

\section{Sintese}

A analise funcional da induistría litica, a pequena quantidade de instrumentos Aefiniveis, a existência de poucos vestigios de fogueiras e as dataçōes indicando ocupaçōes 
sucessivas sepandas por muito tempo, indicam que os abrigos e grutas foram utilizados como sitios de habitaçīo, possivelmente estacional ou temporária, pot grupos muito pequenos de caçadores e coletores nômades, possuidores de culturas materiais relativan. mente simples. As pontas-de-projétil do segundo e terceito momento de ocupaçào, indicam a utilizaçâo do arco, com a possivel ênfase na caça. A raridade dos restos csseos e vegetais, provavelmente devido à má conservação por causa da composição dos sedimen. tos, impediu, no entanto, um major conhecimento da sua alimentaçăo. .

Mais recentemente, também grupos de horticultores Tupiguarani, os Tape, usaram esporadicamente estes locals como abrigo, como vêm sendo utilizados ainda atualmente por acampamentos de caçadores.

Os petroglifos, iniciados pelos primeiros ocupantes humanos, foram sendo renovidos e aumentados pelos ocupantes seguintes, às vezes durante longos periodos de tempo; como as de mais de doís mil anos observados na gruta de Canhemborá e no abrigo da Pedra Grande. O passar de tanto tempo pode justificar perfeitamente as mudanças de estilo que se observaram.

\section{VI - COMPARAÇŌES}

\section{Material lítico e cerámica}

Já vimos como o contexto ou acervo dos artefatos típicos escavados no abrigo da linha Sétima c, em menor escala, no da Pedra Grande, corresponde ao contexto analítico da fase Rio Pardinho, em especial as pontas-de-projétil pedunculadas e com aletas, as pontas-de-projétil lanceoladas, os bifaces grandes alongados e até a presença de um pequeno número de fragmentos de cerámica da tradiçăo Tupiguarani, que caracterizam o que se poderia chamar de momento pós-ceràmico desta fase.

Os sftios da fase Rio Pardinho até agora estudados se encontram no mesmo meio ambiente constituido pela floresta tropical da escarpa do planalto, onde se acham os abrigos e grutas com patroglifos, mas estão af astados $80 \mathrm{~km}$ para o leste, nos vales des rios Pardo e Pardinho. Foram localizados e pesquisados 81 sitios superficiais e, em 25 deles, havia também um pequeno nủmero de fragmentos de cerasmica da tradiçăo Tupiguarani. ${ }^{40}$

Em termos gerais existem também muitas semelhanças entre as pontas-de-projetil pedunculadas e com aletas ou lanceoladas da fase Rio Pardinho e as das fases Umbu, ${ }^{4}$ Itapur $^{42}$ e Camuri, ${ }^{43}$ cujos sitios so encontram sobre o planalto na írea entre o rio $\mathrm{Caf}$ e o Oceano, distanciados de 180 a $300 \mathrm{~km}$ para o leste. Tambejm se assemelham muito is pontas da fasa Araponga, cujos sítios se acham nos vales do alto rio Uruguai $e$ do rio Pelotas, $270 \mathrm{~km}$ a nordeste ${ }^{44} \mathrm{e}$ as da fase Amandá, também do vale do alto rio Uhugual. mas situados a $250 \mathrm{~km}$ a norooste. ${ }^{45}$ Existem também pontas semelhantes nos sitios da fase Panambi, do alto ljuí, situados $120 \mathrm{~km}$ ao norte ${ }^{46}$ e nos sítios do vale médio do rio Uruguai, do chamado complexo de Itaqui, ${ }^{4}$ da desembocadura do rio lbical e do baixo ljui, ${ }^{4 \mathrm{a}}$ que se acham a mais de $30 \mathrm{~km}$ a oeste. Pontas senelhantes aparecem também eos aterros artificiais que sĩo os sítios característicos da fase Patos da planicie litoranea da 
Laguna dos Patos, distanciados mais de $200 \mathrm{~km}$ para sudeste. ${ }^{49}$ Todas estas fases sẫo pré-ceraimicas, mas pontas semelhantes tambĕm aparecem nos sítios da fase ceralmica Ibirapuits, do baixo Ibicur. 50 Aliass, todas as pontas que podem ser descritas como pontas de flecha no Rjo Grande do Sul, salo muito semelhartes.

A distribuiçóo espacial destas pontas - se se toma como centro a área da fase Rio Pardinho - forma, portanto, a partir do leste para o nordeste, norte e norceste até o oeste, um amplo areo voltado para o sul. Assim ocupa a escarpa do planalto voltada para o vale do tio Jacuí e depois a voltada para o Oceano, por cima do planalto chega ao vale do tio Pelotas e ao alto e médio Unuguat, até a desembocadura do lbieui, se encontrando tambèm a sudeste na planície litoranea da laguna dos Patos.

0 ambiente ocupado parece ter sido preferentemente os biomas fechados, isto $\mathrm{e}$. ireas florestadas.

Todas estas relaçōes ja foram antes indicadas em outro lugar, ${ }^{3 r}$ e a posiçắo termporal das manifestaçōes arqueológicas citadas é a seguinte:

A fase Umbu $\hat{e}$ a maiss antiga đe todas e possui trés dataçós radiocarbônicas: $5950 \pm 190$ a.P.: 4000 a.C. (SI-234), $5680 \pm 240$ a.P $=3730$ a.C. (SI-235) e $4280 \pm 180$ a.P. 2330 a.C. (SI-233). A fase Rio Pardinho possui trés dataçóes: $905 \pm 95$ a.P. A.D. 950-1140 (SI-1196), $800 \pm 40$ a.P. A.D. $1110-1190$ (SI-1003) e $605 \pm 40$ a.P.: A.D. 1305-1385 (\$1-1002). A fase Itapui possui duas datap̄ōes: $5655 \pm 140$ a.P. 3705 a.C. (SI-1199) e 1740 55 a.P. A.D. 145-275 (SI-2344). Para o complexo de Itaqui possuimos uma so datagão: $3527 \pm 145$ a.P.: $1428-1718$ a.C. (SI-800), porém não se sabe de que maneira a datação se relaciona com as pontas-de-projétil. Para a fase Camuri: $575 \pm 80$ a.P.: A.D. $1295-1455$ (SI-804) e para a manifestaçdo da desembocadura do Ibicui: $610=65$ a.P.: A.D. 1275-1405 (S1-1195), As fases Amandaú, Araponga, Panambi e Patos n̋ัo possuem ainda đataçôes absolutas.

As dataçōes radiocarbónicas sugerem que as fases Umbu e Itapuí representariam uma tradiçâ̄o antiga de portas-de-projétil que se teria desenvolvido entre ca. 4000 e 2000 a.C. e cuja dispersăo se teria restringido ao ângulo formado pelo planalto meridional no nordeste do Rio Grande do Sul.

Quanto as fases Rio Pardinho e Camuri e as manifestações do baixo lbicuí, possivelmente junto com as fases Amandaú, Araponga, Parambi, c Patos, formariam outra tradição de pontas-de-projectil, esta tardia, que se teria desenvolvido entre ca. A.D. $1000 \mathrm{e}$ 1400 e cuja dispersão teria sido muito ampla. ${ }^{51}$

Em termos mais gerais, as pontas pedunculadas e com aletase as pontas lanceoladas da fase Rio Pardinho, podern ser comparadas com as do periodo IV de J. Bird, ${ }^{59}$ nas grutas Fell e Palli-Aike e com as pontas das camadas III e IV de J. L. Emperaire, na mesma gruta Fell, do estreito de Magalhăes, ${ }^{54}$ G.R. Willey ${ }^{55}$ descreve pontas semelhantes na Pampa. Estas manifestaçốes da Patagồnia e da Pampa foram classificadas por O.F. Menghin no que chamou cultura ou indústria lítiça Patagoniense. ${ }^{56}$ Manifestaçōes semelhantes do território da Provincia argentina de Entrerios, du República Oriental do Uruguai e do Rio Grande do Sul - neste caso se referindo à fase Rio Pardinho - foram classificadas por J. Schobinger como culturas ou indístrias líticas Subpatagónicas." "7

A indústria litica Patagoniense teria se desenvolvido desde o denominado Patagoniense antiguo, ca. $3000 \mathrm{HCC} \mathrm{s}^{58}$ ou $2500 \mathrm{a} . \mathrm{C}^{59}$ ité ca. A.D. 1400 , portanto numa 
faixa temporal que coincide parcialmente com o periodo de ocupaçăo dos abrigos e grutas do Rio Grande do Sul (ca. 1100 a.C. - A.D. 1600). ${ }^{60}$

A ceramica da tradiçăo Tupiguarani encontrada tanto na superficie e nos níveis superiores do abrigo da Pedra Grande e da gruta de Canhemborá, como no momento pós-cerámico do abrigo da linha Sétima, pertence à fase Vacacaí (ca. A.D. 1100-1750) atribuida aos indígenas denominados Tapes, falantes da língara guarani e cuja localizaçioio na escarpa do planal to coincide con a deste grupo étnico, ${ }^{61}$

A Reduçino de São José, nas proximidades da Pedra Grande, foi uma das últimas fundadas pelos jesuitas espanhois no que atualmente te o territórió do Estado do Rin Grande do Sul no século XVII (A,D. 1633-1637). A ceraimica encontrada no local fol classificada na fase Redaçōes (ca. A.D. 1627-1641) que representa a transiçăo entre a cerảmica da tradição Tupiguarani das fases Fuí e Vacacá e a cerămica denominada Neobrasileira. Na Reduçấo de São José teriam sido reduzidos indígenas do mesmo grupo chamado Tape. ${ }^{62}$

\section{Petroglifos}

Pedro A. Mentz Ribeiro descreve quinze sitios com petroglifos que se encontram na mesma esçarpa do planalto, porém distanciados desde 80 até $300 \mathrm{~km}$ para leste dos por nós pesquisados. Os petroglifos se acham gravados em abrigos ou grutas ou sobre blocas. ao ar livre, na parte alta dos vales de tributários do baixo Jacui, como os rios Pardo, Taquari, Cai e Sinos, nos municípios de Santa Cruz do Sul, Venancio Aires, Montenegro, São Sebastiāo do Caí, Portāo, e Taquara. A técnica de gravação é em geral pot polimento, e mais raramente por picoteamento e as gravaçōes, com apenas uma exceçāo, foram também executadas sempre sobre rochas areniticas, ${ }^{63}$

Ribeiro estabeleceu, om 1973, dois estilos ou tradięóes distintos para os petroglifas que descreve. $O$ estilo ou tradição 1 representaris trés fases. A fase A pertenceriam os petroglifos de onze dos quinze sitios estudados: linha Araģa II, Arrojo Grande, Cerro Alegre, Cerro dos Bois I, Dona Josefa, Morro do Sobrado, Bom Jardim Velho, Virador I, Conceiçăo I, Macaco Branco, Moquém. Pertenceriam também à fase A os petroglifos de gnuta da Toca Grande, pesquisada por Eurico Th. Miller. ${ }^{64}$

A fase B estaria representada em um único sítio: Cerro do Baú II, e a fase C em outros dois sitios: Cerro do Baú III e a linha Araçá I. Nestes trés sitios se observant somente alguns poucos sulcos retilineos paralelos que poderiam ser simplesmente poljdo. res do gume de instrumentos líticos.

A técrica de execuçăo, as dimensoes dos sulcos e perfuraçōes e principalmente os motiwos das gravaçōes da fase A do estillo ou tradição I, correspondem, em linhas geras, ao nosso estilo B como se observa nos abrigos da linha Sétima e da Pedra Grande. ${ }^{65}$ Excetuam-se $\mathrm{cs}$ abrigos do Virador $\mathrm{I} e$ Conceiçăo $\mathrm{I}$, ande se observam os motivos que mess se diferenciam.

Os motivos comparáveis, mais comuns nos sitios descritos por Ribeiro, «ॠం:

1) sulcos retilíneos isolados cu agrupados que se unem ou entrecruzam;

2) pisadas de ave ou trictáctilos; 
Petroglifos...

3) sulcos em forma de $\mathrm{U}, \mathrm{V} \in \mathrm{X}$;

4) grades;

5) espinhas de peixe, árvores ou emplumaduras de flecha;

6) linhas quebradas;

$7)$ triângulos, losangos, estrelas, vulvas etc:

8) perfuraçbes isoladas ou mais frequètemente alinhadas, ${ }^{66}$

Nāo se observam as pisadas de felino, os círculos com ponto ou sulco central etc. que caracterizam o nosso estilo $\mathrm{A}$.

Em um único sítio, Certo do Baú L, encontrou una gavaçâo picoteada de um quadrúpede esquematizado, o que corresponde ao seu est

Quatro dos quinze sítios foram escayados. Em trés deles: RS-C-14: Bom Jardim Velho, Virador I e Cerro Alegre, Ribeiro identificou um nivel inferior com pontas que atribuiu \& fasse Itapui, e onde obteve a dataçảo radiocarbonica $5655 \pm 140$ a.P : 3705 a.C. (S1-1199). Nos dois primeiros havia, alem disso, um nivel superior com cerămica da tradiçẩo Taquara, ${ }^{6 \text { " }}$ onde obteve duas dataçōes radiocarbôneicas: $745 \pm 115$ a.P.: A.D. $1000-1320$ (SI-1198) e $630=205$ a.P.: A.D. 1115.1525 (SI-1201).

Em seis outros sitios não escavados, haviu cerảnica da tradição Tupiguarani na sperficie, ou no interior do proprio abrigo ou no exterior àté $100 \mathrm{~m}$ de distảncia.

O fato de que a segunda ocupaçî́o dos abrigos com petroglifos comparáveis ao nosso estilo B se situa na mesma faixa temporal (ca. A.D. 1100-1500), mas em vez do material arqueológico da fase Rio Pardinho se encontra ceràmica da tradição Taquara, propōe um interessante problema até agora nio solucionado, Relembramos, no entanto, qae destes dois sitios ê no Viradot I que se observam os petroglifos com motivos e đimensōes mais diferentes do nosso estilo $B^{69}$ e no RS-C.14: Bom Jardim Velho, havia aperas um motivo gravado: diversos sulcos retilineos que se entrecruzam formando uma estrela. $^{70}$

Entre os petroglifos gravados da Repúbliea Argentina também se encontram freqüentemente conjuntos muito semelhantes tanto na técrica como nas dimensoles e motiwos aos petroglifos do Rio Grande do SuL Os motivos sāo principalmente as pegadas de felino, as pisadas de ave, os sulcos setilíneos, os circulos, os labitintos e es grupos de perfuraçces e se acham gravados, como os nossos, no interior de abrigos e grutas, on então sobre paredōes ou em rochas isoladas. São observados desde o sul da Patagonia (Chubut e Santa Cruz), norte da Patagonia (Neuquén e Rio Negro), Cuyo (San Juan e Mendoza) até o Norneste (Jujuy, Salta, Tucumin, Catamarca e La Rioja) ${ }^{7}$

Há somente uma informaçāo para a Mesopotamin, numa área mais próxima da nossa írea do Rio Grande do Sul, em Yapeyú, na Provincia de Corrientes, gravados sobre rochas toladas na margem do rio Uruguai. Segundo J. Gradin, săo coastituidos de sulcos profundos retilíneos, paralelos ou entrecruzados, formando cruzes ou estrelas e de sulcos sifculares, algumas vezes com outros retilineos irradiando da periferia. ${ }^{72}$

O. F. Menghin estabeleceu trets fases ou estagios para os petroglifos da Argentina:

1) "Pinturas arcaicas" (negativos de maos, cenas naturalistas e figuras geométricas thithito simples]: 
2) "Grabados de pisadas" [estilo de pisadas];

3) "Pinturas y grabados recientes (estilo de paralelas, grecas, grabados finos y simbolos complicados) 7 ?

Os nossos propostos estilos $\mathbf{A}, \mathbf{B}$ e $\mathbf{C}$ podem ser classificados ou correspondem, técnica e formalmente, à sua seganda fase ou estágio, caracterizada pelo aparecimento da técruica de gravaçảo, em oposiçấo a da pintura que caracterizava o primeiro, e representa. da pelo estilo de pisadas.

Alguns dos conjuntos de gravuras do estilo de pisadas do sul da Patagonia (Santa Craz), publicados por $F_{\text {, de }}$ Aparicio, ${ }^{\dagger 4}$ podem servir de exemplo das semelhanças existentes, pois parecem cópias dos petroglifos do nosso estilo A das grutas do Rio Grande do Sul.

Cronologicamente as gravaçoes, e em especial o estilo de pisadas, teriam comegado ca. 2000 a.C. ${ }^{75} \mathrm{ca}, 2500$ a.C. ${ }^{76}$ ou ca. 3000 a.c. ${ }^{77}$ e se estendido até o período imediatamente anterior ao historico.

Alguns dos motivos, como os circulos e meandros gravados com sulcos muito profundos, encontrados principalmente em Cuyo (sul de Mendoza) e no norte da Patagonia (Neuquén e norte de Chubut), representariam influéncias "amazónicas, "7 a

Os petroglifos gravados do estilo de pisadas salo atribuidos por O. F. Menphin aos grupos caçadores do sul da Patagonia, portadores da indústria lítica Patagoniense, a mes. ma que encontramos - na sua forma chamada por J, Schobinger Subpatagonica, incluindo a fase Rio Pardinho - nos abrigos e grutas do Rio Grande do Sul também relacionada com petroglifos que correspondem ao mesmo estilo, ${ }^{79}$

A. M. Lorandi de Gieco, ${ }^{30}$ estudando os petroglifos gravados do Norveste (norte de La Rioja, sul e centro de Catamarca), estabeleceu quatro estilos distintos. Os petroglifos estáo gravados por picoteamento ou polimento em paredồes ou sobre blocos ao ar livte. Entre os cinquenta e um motivos descritos, encontramos ao menos treze compariveis aos dos petroglifos do Rio Grande do Sul $(4,19,20,23,24,27,30,32,33,35,36,37$ e 40., ${ }^{\text {s1 }}$ Porim somente quatro destes motros aparecem como sendo caracteristicos de dois dos quatro estilos estabelecidos.

No seu estilo I aparecem "huellas de felino" $(4)^{62}$ e no seu estilo II, "hucllas de fiandô o de aves o de pajaros en general" (19), "Tíneas onduladas" (30) e "puntos o diseños formados por puntos" $(32)^{83}$

No enianto, estes motivos constituem sempre somente alguns dos elementos mais simples que serviram para caracterizar os estilos 1 e II e estào sempre acompanhados de outros muito mais complicados, como representaçōes de llamas, felinos, emas, șurios, rostos ou figuras bumanas etc.

Apesar disto, é possivel reconhecer nas ilustraçōes muitos eonjuntos de motivos semeihantes aos nossos, qque nđ̆o incluem motivos mais complicados.

\section{VII - SINTESE}

Foi possivel constatar que na encosta do planalto meridional do Brasil, no Estado do Rio Grande do Sul, se encontram abrigos e grutas em cujo interior se acham gravados 
petroglifos que podem ser classificados no estilo de pisadas, muito difundido mais para o gul e ceste no territôrio argentino. Além disso, como na Argentina, os petroglifos do Rio Grande do Sul parecem também estar relacionados com as pontas-de-projétil peduncu. ladss e com aletas incluidas por 3. Schobinger nas indústrias líticas Subpatagónicas, atribuidas aos caçadores da cultura Patagoniense, a quem O.F. Menghin atribuiu também os petroglifos deste estilo.

A faixa de termpo dentro da qual cremos poder situar os norsos petroglifos. (a. 1100 a.C. - A.D. 1600) também corresponde à do estilo de pisadas na Argentina (ca. 3000 a.C. - A.D. 1600).

Nฐ̃o é de nenhuma maneira impossivel que uma mesma tradiçẫo cultural - inđústria litica e estilo de petroglifos - se tivesse estendido sobre essa imensa distancin, de mais de dois mil e quinhentos quilòmetros, desde o sul da Patagonia até o centro do Rio Grande do Sul, porém nío possuimos nenhuma informaçito segura a respeito do verdadeiro sentido da dífusaio. A distribuiçấo dos abrigos e grutas com petroglifos ao longo da escarpa do planalto, penetrando pelo vale do rio Jacui, sugere a idèia do planalto como um obstáculo anteposto e do vale deste rio como uma rota de penetraçĩo de tradiçôes provenientes do sul. Alem disso, os sitios com petroglifos deste estilo na República Argentiaa se contam por centenas e apresentam uma imensa dispersầ geográfica, cnquanto que no Rio Grande do Sul foram encontrados até agora somente em dezoito locais concentrados numa área restrita e não hả not ícia da existència de petroglifos semelhantes mais ao norte sobre o planalto.

Tudo leva a crer, portanto, que o sentido da difusco tivesse sido do sul para o norte.

Por outro lado se coloca um interessante problema quanto ao caminho tomado pela postulada difusão conjunta das tradiçסes de pontas e petroglifos. Tanto as pontas-deprojétil pedunculadas e com aletas do Patagoniense ou Subpatagoniense, como os petroglifos gravados de estilo de pisadas, faltam inteiramente na pampa húmeda que, no entanto, se afiguraria como a zona de passagem obrigatória. ${ }^{84} \mathrm{~A}$ área mais próxima do Rio Grande do Sul onde se observa a concentraçĩo de petroglifos deste estilo - coni excecão do único sítio reportado na Mesopotamia, em Corrientes - se encontra no Noroeste da Argentina ( $L a$ Rioja e Catamarca), mais ou mesnos sobre a mesna faixa de latitude, porém mais de $1200 \mathrm{~km}$ a oeste e em ambientes completamente distintos. ${ }^{\text {s. }} \mathrm{J}$. Schobinger pensa que se deve procurar o caminho da difuslo das pontas-de-projétil pedunculadas c com aletas, entre a Patagónia e a pampa seca, por um lado, e a Mesopotamia, a República Oriental do Uruguai e o sul do Brasil, por outro, em um amplo arco estendido mais para ceste, atravessando o territôrio das Prowincias de La Pampa, Cordoba o Santa Fé. ${ }^{6}$ Parece que o mesmo se poderia pensar a respeito do caminho da difusio dos petroglifos gravados.

Outro problema se liga à ecologia dessas manifestaçées culturais. As pontas-de: projetil atribuidas is culturas Patagoniense e Subpatagoniense, sad encontradas desde o Etreito de Magalhães até o vale do rio Iguaçu, e seus postulados portadores, os caçadores patagónicos, teriam portanto ocupado muitos ambientes diferentes, na sua longa trajetoFla deste o extremo sul do continente até o plunalto meridional do Brasil. Énquanto isso, os petroglifos do estilo de pisadas se encontram, na Argentina, exclusivamente em âreas e clima árido ou semíárido, onde as chuvas são escassas, variando desde o máximo de 
$700 \mathrm{~mm}$ no monte occidental de Cuyo e no Noroeste, até menos de $150 \mathrm{~mm}$ na estepe da Patagonia. Exceptua-se somente a itha de clima subúmido encontrada em Tucuman, qque permite algo assim como uma floresta subtropical.

Os petroglifos do estilo de pisadas não sắo encontrados, como vimos, nem nọ campos abertos da Argentina, Uruguai e Rio Grande do Sul, nem na savana do Chaco e da Mesopotamia. Por isso mesmo, parece ainda maior o salto, quando reaparecem no interiot da floresta tropical da encosta do planalto meridional, no Rio Grande do Sul, numa área de clima subtropieal umido, com mais de $1500 \mathrm{~mm}$ de chuva.

A situação dos abrigos e grutas, na transição entre dois biomas distintos - locall. zados dentro de um bioma fechado, a estreita faixa da floresta tropical da escarpa, mas abrindo para um bioma aberto, os campos cobertos de gramineas que se estendem para o sul - seria ditada pela necessidade de explorar as dois ambientes ao mesmo tempo, uma situaçso caracteristica dos caçadores tropicais.

\author{
Bolsistas do Conselho Nacional de Pesquisa (CNPq) \\ Departamento de Ciencias Sociais \\ Universidade Federal do Rio Grande do Sul \\ Porto Alegre, Brasil
}

\title{
AGRADECIMENTOS:
}

As pesqaisas se tornaram possiveis de inicio por msio do Programa Nacional de Pesquisas Arqueobogicas (PRONAPA) financisdo pela Smithsonian Institution dos Estados Unidos da Aanérick, depois por bolsas e muxflios do Conselho Nacional Se Pesquisas (CNPq) e do Instituto do Patranósio Histótico e Artístico Nacional (IPHAN). Os trabalhos de Laboratónio estâo sendo executados no Gabinete de Arqueolotia do Instituto de Filosefa e Ciencias Hamanas da Universidede Federal do Rio Grande do Sul, em Porto Alogre.

Todas as đataçōes radiocarbônicas fonm ececutadas pela Smithonian Institutian Radiocartoa Labocatory, Radiation Biolegy Laboratory, 12441 Parklawn Drive, Rockvile, Md. 20552, pot un especial obsóguio dos Dt. Clifford Evans e Betty ), Meggers.

Colaboraram em difetentes mómentos dos trabahos de eampo: P. Josl Pivetta, P. Danid Cargnin e P. Dorvatino. Dotta, do Museu do Patronato Agrícola Antonio Alves Ramos de Sasta Mariai; Dr. Gastío Baumhardt, do Museu do Colégeio Mauá de Santa Cruz do Sul; Prof. Victot Hugo O, da Silva, da Universidade Federal de Santa Marax, e as Prot, is ftala Irene Brasale Becket e Maria Helena Abrahío Schorr, do Instituto Anchietano de Pesquiss (LAP) da Universidade do Vale do Rio dos Sinas (UNASINOS). Estas duas últimas colaboraram com os sutores ma cópis dos petroglifos dinetamente das: puredes da gratu de Canhem borá 6 do abrigo da Pedra Cirande.

Nos trabuthos de laboratório, o Prof. Ervino Barth, me ępecu Monitor da disciptina de Antropo logia, executou a eobia fos petroghifos, a Prof," Beatriz Ana Lohnes, na ćpoes bolesta do Conselho

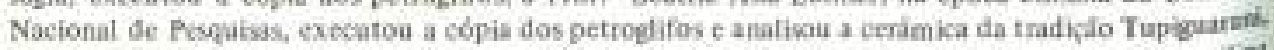
e o Prof. Sergio Luic Carvalho Lrite, bolsinta da Uaivessidade Federal do Rio Grande do Sal, anxilad na rextaço final.

Agradecenos tamberm ao Prot. Eduardo Trebin, e aos Sr. Helitemar Basdur Rcpike, Lincolr Steuernagol e a famitia Manske, de Canhembork, manicipio de Nova Palma. 


\section{NOTAS}

${ }^{1}$ MONTERO, Carlos A ugusto F. "Geonoofologia." In Geografla do Brasilt - Gnande Regiōo Sul. Rio de Janeiro, IBGE, CNG, 1963, v. 4, t. 1, p. 66, 74, fig. 1.

${ }^{2}$ RAMBO, 5.J, P. Balduino. A fisianomía do Rio Grande do Sul. 2. ed. Porto Alegre, 5elbach, 1956. p. $317-41$.

Ninguém meltot do que B. Rambo descreveu o aspeto da boch de serra do rio Jacar: "As ladeiras empinadas da muraliha, emengindo de planicies pantanosos, surgem cobertas de mata, frequiestes vezes interrompidas por peraus verticais, e confinam com a parisagem campestre do topo. Em breve, porèn, o Jacuí abre uma profunda 'boca de Serra' na escarpa. Um ollar para dentro desse portal do Jacuí, mostrn uma paisipem muito regular, formada pelos reposteiros rochosos entre os vales laterals, todos ingremes, todos tabulates ns parte superior, todos cobertos $\delta e$ mata virgem, $O$ vale é relativamente estreito, mas a máltipia Gestruiçăo das barseiras marzinais đeu ensejo a norescentes cotỏnias cota arrozais junto ao nio, milliarais nas porçbes plantas e belos vinhedos nas encostas" (p. -341).

Ou a salda dos tíos lbicuf-Mirim e Toropi do planalto, no município de Sĩo Pedro do Sul: "Para o sal, a borda đa Serra continus ainda am bom trecho, resolvida em osperōes e contrafortes cobettos de mato. Onde o tbicuí os rompe para diryir-se definitivamente para o oeste, obseman-se todas as

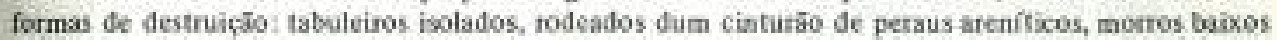
com poueos testes de medffiro, coxilhas rebaisadas e porç̋es planas ao nivel da Campanha. Nesta twnz, abundantemente coberta de vegetaçjo silvítica, desenvolvem-se os núcleos coloniais de Sīo Pudro"' (p. 318).

${ }^{3}$ MONTEIRO, Carlos Augusto F. "O clima da tegiäo Sul". In Geogrefia do Brast - Grende Regiáo Sil. Rio de Janeiro, IBGE, CNG. 1963. v. 4,t. 1, fiz. 66.

4 1d. ibid. p. 154, fig. 64-6, est. 2.

"GALVĀO, Marilia Velloso. "Regibes bioctimíticas do Bradi." In Rev. Bratileira de Geografar. Rio de Janeiro, IBCE, 1967. v. 29, t. 1. p. 27.8 e mapa.

"ROMARIZ, Dora A. "Vegetaçlo." In Geografia do Bresil - Grande Regiño Sul. Rio de Janeiro, IBGE, CAC, 1963, ४. 4, mapa-

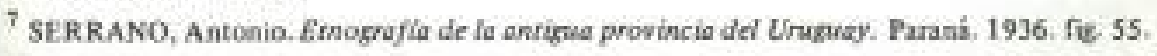

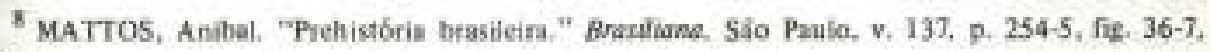
1938.

"TUPi CALDAS, 1. "Litoglifos de Sjo Potro - Tentativa de versio." In Revisna do Insrinuto Historico e Geogrifleo do Rio Gronde do Sul.Ano 14, $4{ }^{\circ}$ trimestre, 9 p., 1 fig. Porto Alegre, Globo, 1940.

A fotegrafia regroduzida, que representa uma pequena porçấo da área central do paind priscipal do abtigo da Pedra Grande, está imertida e do grande número de granuras da írea fotografada, apertas umas vinte foram ressaltadas. Numa aproximasẩ característica da época, influenciado pot Alfredo

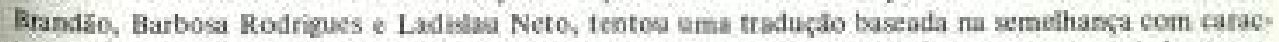
tetes ideogrificos e alfabéticos sumtrios, etruseor, ibérices, cquimicos, egipcies, cretetises, hebraicas e srezor antigos. No entanto, como atribuitu a inscriçio a mamelucos, indicando o lotal de trma Missio e

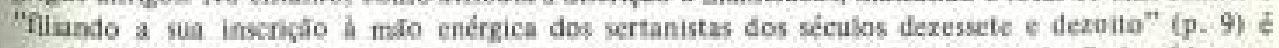

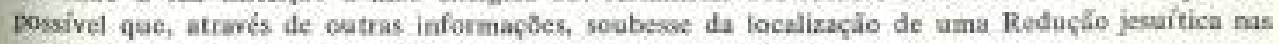
Droximaidades: Ver: R.S-SM-7: Pedra Grande, Material arqueoiógico.

${ }^{10}$ BROCHADO, Jost Proenza. "Pesquisas arqueológicas nos vales do tjuí e Jacuit" in

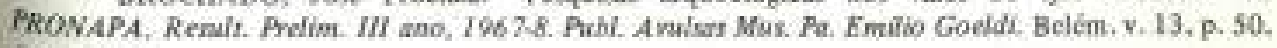
$534,1969$. 
Comunicap̧os a respeito dos petroglifos da gruta de Canhemborá e dos abrigos da linha Sétima e da Pedra Grande, foram apreseatadas pelo primeino des zutores na XXI Reuniäo A mual da Socizdaite Hrasileira para o Progresso da Ciếncia, em Porto Alegre, a 30 de junho de 1969, e no Primer Congreso Argentino de Arqucología, reunido em Rosario. Provincia de Santa Fe, de 23 a 28 de majo 4 e 1970.

11 BROCHADO, José Prosnza, "Extensía das pesquasas arqueológicas nos vales da Jacuí e

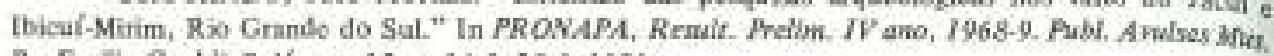
Pa. Emilio Gookdi, Belúm, v. 15, p. 14-5, 25-6. 1971.

12 SCHMITZ, Pedfo Ienácio \& BROCHADO, José Proenza: "Datos para una secaencia cultura del Estado de.Rio Grande do Sul (IIrasil)."

Apresentado as Segundo Congreso de Arequeologia Argentina, reunido em Cipolieti, Província de Río Negro, em maio de 1972 , pelo primeiro dos sutores, foi distribuido, mimeografado, como a

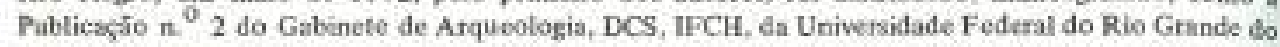
Sul, Porto Alegre, 1972

A ruferéncia à fase Cashemborá se acha na p. 12, no mapa e no qquadro cronológico-

Uma versio anterior do presente artigo: "Aleros y cuevas con petzoglifos e indústris lítica de la escarpa del planalto meridional, em Rio Grande do Sul, Brssil", redigida pelosmesmos dois autores, foi publicads em Anales de Arqueologia y Etnologín, Mendoas, t. XXVI - XXVIII, p. 39-66, 1972-1973.

As vírias fotos apresentadas podern set comparadas com as cópias dos petroglifos publieadas no presente artigo.

13 BRCCHADO, Jasé Proenza. "Extensĩo das pesquises arqueológicas nos vales do Jacuí e Ibicui-Mirim, Rjo Grande do SuL" In PRONAPA, Rerbil, Prelim. IV eno, I968-9. Publ. Avulas Mus. Pa, Emilio Goeldt.

14 Ficou estabejecido, por conveniéncia, que se escreverá Tupi-Guarnai, sempre que se referir aos grupes stnoeráficos utuais ou históricos que falam ou falaram linguas da fannia lingüistica Tupi-Guarani. e st escreverí Tupiguarani, sem hifen, quando se referir à tradicjo cerainaica destes grupos. Tanto para economizar espaco como para simpificar a exposiçio, se empregari o termo tradiçio Tupiguaraal no sentido de tradiçóo cenimica Tupiguarani e se falari simplesmente dos Tupiguarani çuando nos referimos sos indígenas portadores da tradiçío cetaimica Tupiguarani-

A tradiçho cerienica Tupiguarani foi estabelecida no II Seminário do Programa Nacional de Pesquisas Arqueológicas, reunido no Museu Paraense Emilo Goeidl, em Belém, Pará, de 14 a 29 de julho de 1968. Resuataram deste Scminátio as scguintes publicecôes:

BROCHADO, Jow Proenza; CALDERON, Valentín; CHMYZ, Igor; FERREIRA DLAS, Ondemar; EVANS, Clifford; MARANCA, SÍvia; MEGGERS, Betty I; MILLER, Eurico Th.; NÁSSER. Nássaro A.S; PEROTA, Celso; PIAZZA, Walter F.; RAUTH, José W.; SIMÖES. Mirio F. "Arqueologia brasileira em 1968. Um relatório pretiminar sobre o Programs Nacional de Pesquisas Arqueológicas." Pub Arulsus Mhs. Fa Emilo Goeidh, Belém, v. 12, p. 19, 1969.

PRONAPA, Programa Nacional de Pesquisas Arqweol6gicas. "Brazillan Archacolagy in 1968: An interim report of the National Program of Archusology Research - PRONAPA." In American Antiquity, Salt Lake City, $36(1): 12-6,1970$.

A tradiçto cerimica Tupiguarani è curacterizada pelos seguiates traços diagnósticcos: "Sites are of superficial depth, implying stort village permanence, and secondary urn burial was pacticed in or adjacent to the habitation area. Stone artifacts of nearly universal occurnence ane nukes, choppers, abraders, and luge polished celts. The tembeti, or lip plag, is a characteristic ormument. Pipes are also common. Diagnostic techniques of pottery decoration are painting os a white-sipped sarface. corrugation, all-oyer bruching and fingernail marking. Also widespread are red slipping, finges grooving nicking af the rim, incisian, punctation, and fingernail ridging. . . A great variety of vessel shapes sccurs, ranging from rounded howls to large angular-shouldered burial urns; bowls are-often square or oval rather than circular in oatline" (p. 12).

Uma caracterizaçio desta tradição cerámica no Rio Grande do Sul so encontra em: SCHMIT2. Pedro Ignício e BROCHADO, José Proenza. "Datos. ..", p. 19-21. 
15 BROCHADO, José Proensa, "Migraciones que difundieron la tradicióo alfarera Tugiguarani." 1s Relaciones de is Sociedad Argenting de Antropolog is, Buenos Alues, v. 7, p. 14, 23, 29: fie, 1, 2 , 1973.

BROCHADO, Josd Proenza. "Contstos entre europeus $\mathrm{e}$ indigenas - Um estudo de aculturap̧o

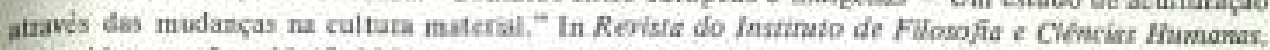
Porto Alcgre, x. 2, P. 1147, 1974.

16 SEMINȦRIO DE ENSTNO E PESOUISAS EM STTIOS CERĀMICOS. Terminologia argeoológica brasileina para a cerrimica." Centro de Ensino e Pexquisas Arqueologicus. Manuais de Angaeologia n. ${ }^{\circ}$ 1. Curisboa, Universidade Federal do Paransi, 1966.

A referida terminolegis foi estabelecida ne I Seminirio do Programa Nacional de Pespaisas Anqueológicas, reuniob ne Universidade Federal do Paraná, em Cuajtiba of Paranaguí, Paraní, de 5 a 29 de outubro de 1964, tendo contribuido: Märio F. Simōes, Nússare A. Ue Souza Nasior, Valentín Calderón, Maria Heloisa Fenelon Costa, Ondemar Ferreira Das Junior, Fernando Altenfeldet Silva. Ghisbene Velasquez Hudriak, Igor Chmyz, José Wason Rauth, Po. Joāo Aifredo Rohr, S.J., Walter Pasza, Luiz de Castro Faria, Maria da Conceiçaio de M.C. Bekea, Herbert Baldas, Paulo Duarte, Oldemar Btase, Re. Início Schmitz,S J., Jook Proenza Brochado e Furico Miller. Ver verbetesi Cerámiea Neobeasileira $(\mathrm{p}, 12)$ e Tradiçẩn $(\mathrm{p}, 20)$.

17 RIBHRO, Pedro Augusto Mentz. "Inscriç̄es rupestres no vale do Rio Cai, Rio Gramde do St (Brasil) (Nota Prévial." In Anoles de Arqueología y Etnología, Mendoxa, v. 24-5, p. 124, 1969-70.

RIBEIRO, Pedro Augusto Mentz. "Petroglifos do sitio RS-T-14: Morro do Sobrado, Montenezjo - Rio Grande do Sut - Brasil," In Theringia, Mis. Riograndense Ciénciar Neturuis, Antropologla. Porto Alegre, V. 2, p. 6,8, 1972.

RiBeIRO, Pedro Augusto Mentz, "Os petroglifos de Cerro Alegre, Sunta Cruz do Sul, Rio Grande do Su1, Brasil - Nota Previa." In Revista CEPA, Centro de Ensino e Pesquisa Anqueológica, Santa Cruz do Sul, v. 1, p. ?, 1974 ,

RIBEIRO, Pedro Augus to Mentz (fd,), BALIMHARDT, Castão Carlos, MARTIN, Hardy Eimiro, HEUSER, Lothar Frederico, STHINHALS, Roberto. "Novos petroglifos ma eneosta centro-oriental da Sema Geral, Rio Grande do Sul - Brasil. Nota Privia." In Mured Colegio Mand, Antropologia, Santa Cruz do Sul, v, 2, p. 13, 1973.

${ }^{18} \mathrm{O}$ interior da gruta pode ses bastante úmido cm determinadas ocasibes. Durante os trabalhos de 1971, por ocasiăo de chuvas caídas na tegibo, we observou forte infitraç5o de igesa, principalmente

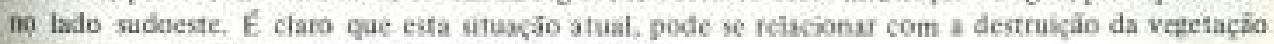
natural que anter recobril a parte vuperior do paredióo.

\section{to GRADIN, Carlos J. "Notas sobre el arte rupestre arpentino."}

Este artigo, Catado de 1969, foi apresuntade ao Segundo Congeso de Arqueología Argentina, masido en Cipolleti. Provínda de Río Negro, em maio de 1972, tendo sido, na ocasito, distribuido. mirncografade, em 16 pizithas, que í a versio que utilizamos.

20 Virias pessoas, imatinando que os motivos do tipo 2 teprescritassem setas indicando onde se:

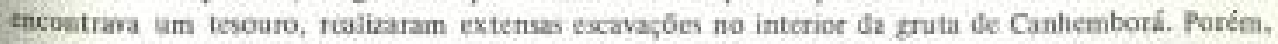
como cavaram ptincipalmente para o interior das paredes da gruta, na sua base, penetrando no arenito

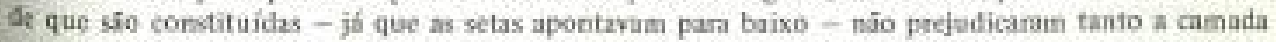
atqueologica depositada solve e piso, excepto talvez ao lado sudoeste. Estas escavapoes romperam u patede do fundo, consunicando a cámara principal com uma outra, menor, existente por detrís, que antes nio era praticivel.

No início des trabalbos de 1921, foi secessairio, portanio, em primeiro lugar, esvariar o interior 4t gruta de todo o material escavado das panedes e acumulado no seu crintro. Este material remorido, remposto principalmante de arenito um diversos gaus de decoenposiço, foi cuidadosamente

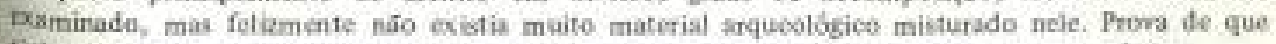
tibhum sido perturbadas quase que semente camadas de sed imentos arqueolocicamente estêreis. 
21 Ver nota 14.

22 Nas proxienidudes da gruta de Canbesmbori, pooco além do final do seu talude de entrada, foi observado, superficialmente, também algum material urquoológice, composto de nácleos e lasean semelhastes al matéria prima e ma eparéncia aos encontrados nas camidas asqueoiógicas do seu interior.

23 A sigla Si e a mumeraçio se referem uo labotatório onde faram execotadas as dataç6es radiocarbōnicas: Smithsonian Institution Radjocscbon Lałoratory.

24 Nas proximidades do patediso onde $s$ abre a gruta do lajesdo dos Dourados, se enconta $\mathrm{mm}$ grande bloco isolado em cuja face se observam também alguns petrogifos. Porém, ma ocasiấo da visita (1972), estes nibo foram devidamente copiados por faita de tempo, nem o local prospeccionado comb Gevia.

${ }^{25}$ Estas condiçōes se déo principalmente numa espécia de rodapé de cerca de Im de altuta, localizado na parte inferior da parede do fundo da gruta, onde se concentra um número tấo grande de perfurą̧ōes, de dimenwes as mais variadas e tấe erodidas, que não sabenos se atribur 4 as ao trabalho

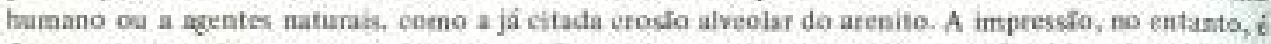
de que aqui, como em eatros hugares, perfuraçoes naturais tetiam sido modificadas pelo homem $e$ perfurspótes artificials ampliadas pela enosio alveolat.

26 Vet nota 19.

27 Ver nota 19 :

${ }^{28}$ Nos trabulhos de 1972, foi necessirio, inicialmente, remover todo o acúmule de sedimentost esconbros escorridos ao redor do ángulo núnoeste da parede restante do fundo, para aleançar o piso de ocupaço subsacente. $O$ escormento foi provavelmente causado pela construça de um caminbo que contoena o pared Jo am pouco acina da abertara dos abrigus.

29 Retirados os escombros e cscavada a camada arqueolózica, se observou que os petroghfer

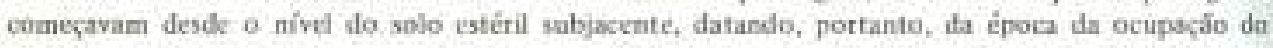
abrieo.

${ }^{30} \mathrm{O}$ bloco qoe forma o abrieo da Palra Grands, com o weu grande comprimento \& pouca espessara, realthente lembea um enorme pano de muro, isobdo e semiderraido ras extrumidades. No sea prolongamate, alguns metros para SSE, se encostram outros restos de faredoes, teunidos, tame que formando um recinto. Consta que astigamente todo o conjento, que atuslenente surge de forma abrupta do fundo relativam crate plano do vale, estaria rodesdo di vesetaçlo cerrada que a excondefia em parte.

${ }^{31}$ E interesante que, apesu das prandes dimenseos da parede do fundo do abrigo da Podn Grandc, os petroglifas se encostrem concentrados unieamente nas áreas descritas. Na face oposta do bloco, também nio se observa nentum.

32 Inicialmente o extenuo sitio cerämico superfi-ial localizado atrifs do abrieo da Pedra Grande fof inclufdo ea subiase $\mathrm{H}$ da fase Vacacai da tradiçâo Tupiguarani, porque a cettim ica ptoveniente dele nĭo pòde ser seriada juntamente com o que passou a ser considerada a subfase $\mathrm{A}$ da mesma fase.

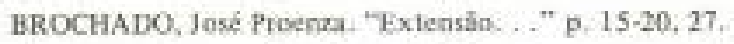

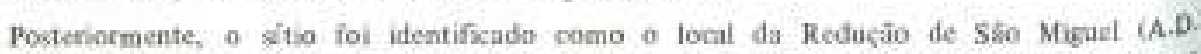
1632-\$638) perçue a sa posiçio geográfica comespondia ate certo ponto com as coordenadast es situajắo desta Redupáo, próxima do rio Toropi, segundo a mapa das Redaçóes Jesuíticas orgarizado polo Pe. Luiz Gonxaga Jareer, S.J. icm 1936.

Ver PORTO, Aurcilio. Histónia đas Misebes Orientais do Uruguai. Porto Alegre, Selbachi 1954.

Esta identificação-tentativa foi apresentada em:

BROCHADO, Josd Proenza. "Contatos entre curopeus e indigenas - Um estudo de aculturanto

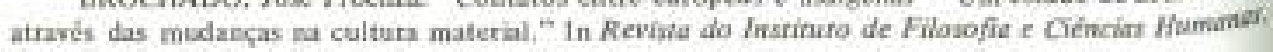
Porto Alegre, ₹. 2, p 14, 28, 1974. 
BROCHADO, Josê Proenze \& SCHMITZ, Pedro Ienicio, “Aberos y cuevos....", p. 62

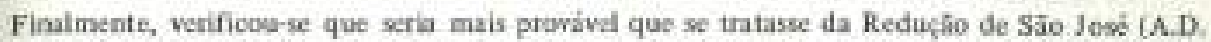
1633-1637). Esta ideatificaçio foi feita com base num texto de:

IAFGE,R, P. Luiz Gonzage, S. 1. "As primitivas Reduçồes Jesuíticas do Rio-Grande-do-Sua." In Toma Fornowpilha, Porto Alegre, Selbach [1935] \& 1, p 3251.

"XIII - SÉ Jose [...] Diz. Techo (voL. IV, 197 e 271) e Charlevoix (II, 327) que no medo dks azduçbes de S. Miguel es. Tomé estanceavam infiéis que, reunindo-se espontancatsente num lugat coberto de selvas, denominado Itacuatí (pedra pintata), levantaram casas e um tempio, mandando depols uma embzixala ao p. Rometo a suplicar-lhe nấo es esquecesse, pois que tambim cles de¿javam ser cristios e renunciar ao demònio,

"Vimamente impressionado, dirigia-se o padre a Itacuati, e, em presenca de 350 famflias chantou

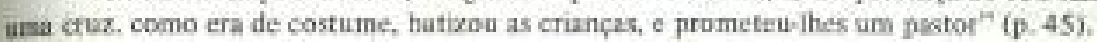

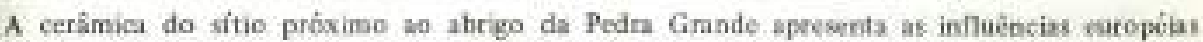
características do que denominamos a fase Redncoues e nenhum outro sítio, na área, se aproxima mais da descriffo como pedra pintada do que este isenso bloco com sus face coberta de petroglifos gravados e pintados. No entanto Jaezer localiza a Reducio de Slo Josk na marzem dircita do rio Toropi e năo ne esquerda, onde se acha o abrięo da Podra Grande:

"Entretanto inclinamo-nos a cret que S. Jose đemosava à mangem firtita do Totopi, não miro distante da vila de São Vicente" (p. 45).

Mais informaçōes a respeito desta Reduçilo aparecem em:

PORTO. Aureio. Op. cit., p. 102-2.201, 219 e 270.

33 A gruta de Canhemborí e os abtigos da liaha Sétima se encontram no município de Nova Paima; a gruta do lajeado dos Deurados, no município de Sobtadinho, na margem oposta do Jacur; e o abrigo da Pedra Grande ino minkípio de São Pedro de Sul

34 R.ALPH, E. K.; MICHAEL. H. N.; HAN, M. C. "Radiocirbon dates and reality." In MASCA Newalerier, Applied' Science Center for archerology, Phadelphla, The Unversity Museum, University of Peansylvania, ₹. 9, L. I, p. L.20, 1973.

35 SCHMitz, Pedro lenício (Ed.y: LA SALVL, Femando; NAUE, Guilherme: DECKER, Itala Irene Basile, BROCHADO, Josi Proenza; ROHR. Jojo Alfredo e RIBFIRO, Pedro Auzusto Mentz. "Arqueologia no Rio Grante do Sal." In Pesquisas, Ancroporogia N. "I6. Instituto Anchietane de Pesquisss. 58 p. Findos Leppolalenses, Sỉo Leopoldo, v, 5, p, 24-55, 1967.

SCHMITZ, Pedro Ignicio e BROCHADO, Jow Proenza. "Datos..." s. 11-3.

BROCHADO, Joot Proenz.; "Migraciones,... ", p. 13-23, tig. 1, 2, 4.

BROCHADO, José Proeraa. "Desarrollo de is tradición ceraimica Tupiguatani (A.D. 500-1800)." Stgunda purte de: "Migaciones que dinindicros la tradición alfarera Tupiguarans." Gabinefe de Anqueologia, DCS, IFCH, Universidade Federal do Rio Grande do Sol Publicaçío n. ${ }^{\circ}$. Simmerafudo, Porto Alagre, p. 25-8, 31, 1973.

36 LATHRAP, Donald W. (Ld,); WILEY, Gondon R. (Ch.); D1 PESO, Charles; RITCHIE, Nillam A; ROUSE, Irving e ROWE, John H. "An archasological classification of culture contact nhations" In American Anriguiby. Salt Lake City, 2212):9-11, 1956.

A situaçº de contate cuitural A.1. definida no artigo acima, foi discatida mais longamente, com

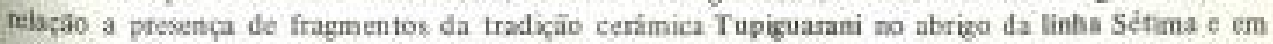
outros sítios da fase Rio Pandinho pós-ccràmica, om:

BROCHADO, José Procnz: "Desarrollo...,", p. 23-8.

i7 Ver nots 35

Um resumo das curacterísticas mais importantes 由 fase Rio Pandinho pode ser encontrado em:

SCHMIrZ, Pedro Ignácio e BROCHADO, José Proenza. "Datos....", p. 12-3. 
"La fase Rio Pandinho, que sịgue, reflẹ̆a un aumento demogrifico notable con relación a los grupos anteriores. Los sitios estin casi todos ubicados en el valle del ría Pardinho, afluente del río Parub, pero aparcecen también en el valie del Jacui. For ocasión do muestra primera imestigacián estudiamos B1 sitios, casi todos con grande abundancia de material. Infelizmente el fifea E intensamente cultivada y las materiales aparecen todos en la superficie del terreno en las chacras. Los sitios son a cielo abicrto y se ubican de preferencla en bajas altitudes, sobee lomas, cerca del rio.

"Los instrumentos mfs abundantes son pastas pedanculadas y con aletas, semejantes a lax $\$$ el período IV de ha vecueacia det Estrecho de Magallanes; aparecen adenís, puetas lanceotadas, cuchillos bifaciales, raspadones en forma de babosa (timaces, bifacts, peçueños raspadores peduncalados raspadores zrandes y chicos, pkeos, perforadores de pantas muy larghs, bolas de boteadora muy abundantes, moletas, tactas pulidas. En una cuatta parte de los sitios aparecen fracmentos intrushos de atfarcria Tupiguaraní.

"La gran castilad de bifaces y raspadores grandes pareoun conectar esta fase con la de las bifaces que banteeede. El grupo es netamente cazador, com más estabilidad $y$ un gran sumento demográfico. Parvec laber sido tan fuerte que impidió el aceso de los portadores de la alfarería Tupieanant at valle que ocupaban. Camo se trata đe una tegiỏn bosensa, que bordea el campo, san bien netos los clementos de ambos ambientex: por un tado, las bifaces, lai hachas, grandes raspadores; por otro, las puntas pedunculadas y les bolas de boleadona. . .

"En la parte final de esta fase, se produjo d contacte con los Tepiguanani, que ocapan el airea posiblemente en el siglo IX AJ.C. Ubicamos la fase Rio Pardinho tentativamente entre la mitsd del primer mifenio y la mitad del sezundo milenio d,J.C., llegando, posalemente, hasta la Comauista ....

"Lo que parece caracterizar esta region đel Estado, es un retrazo cuttural consderable en relación a áreas más meridionales o septeatrionales, en donde elementos parexidos o ldénticos se han desarrollado (puntas, petroglifos, bifaces ete.) y que le di un aire de fefogio, por que realmeste 9 encuentra logos de las gandes rutas de cum unicación. "

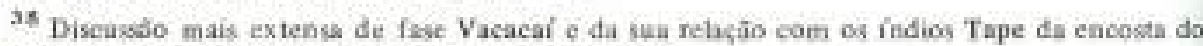
planalto meridional no $R$ io Grande do Sul, se encontra em:

BROCHADO, Jok Proenza. "Pesquias arqueob́́gicas nos vales do ljuí e Jacui," In PRONAPA.

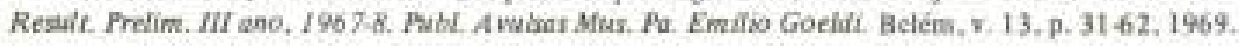

BROCHADO, José Proenza. 'Fxtenski...", p. I5-20.

BROCHADO, Jasé Proenza. "Migraciomes. ." p. 7.39

hROCHADO, José Proenza. "Desarrollo. . "

HKCCHADO, José Proenca. "Contatus...", p. 14-28.

SCHMITZ, Pedro Ignácio e BROCHADO, Jowe Proenza. "Datos.. it, D. 21.

39 Ver nota 32.

40 Ver notas 35 e 37.

41 MILLER, Eurico Th. "Resultados preliminares Gas escavaçöes no sítio pré-oerárnico RS-L.N-1. Cerrito Dalplaz," In theringle, Antrogologia n. ${ }^{\circ}$ 1. Museu Riograndenise de Ciencias Naturais, Potto Alegse, D. 43-112, 1969.

${ }^{42}$ MILLER, Earico Th. "Pesquisas arqueológicas em abrigos-sob-focita no patdeste do Rip

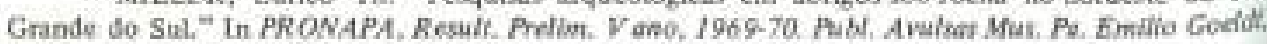
Belfm, v. 26, P. 15-8, 20-1, fig. 3-5, 1974.

43 MILLER, Eurioo Th. "Pexquisas arqueológicas efetuadas no nordeste do Rio Crando do Sel," In PRONAPA, Renult. Prelim. II eno 1966-7, Pabl, Avulus Mrus, Pe. Emilio Goelidi, Belém, v, 6, p. 15. 21, fig. 5, 1967.

MIL LER, Eurico Th. Tesquias arqueológicas efetundas no Planalto Meridional, Rio Grande $\$ 6$

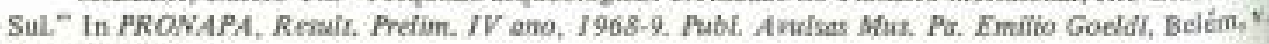
$15, \mathrm{p}, 44,1971$. 
44 MILER, Earico Th. "Pesquikas arqueológicas efetuadas no Planalto. . .", p. 43-4,54.

45 MILLER, Eurico Th. "Pesquisas arqueotogicas efetuadas no notoeste do Rio Grande do Sul,"

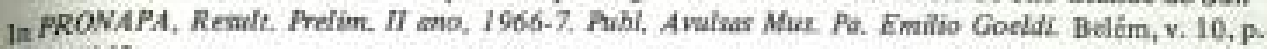
;6 $7,1969$.

46 BROCHA DO, Jooé Proenza. "Pesquisas arqueológieas. ." " p. 35-6, 50-1. fig- 10.

47 MLLER, Eurico Th. "Pesquisas arqueofógicas efetuadas no oeste do Rio Grande do Sul Campenha-Miswốes." In PRONAPA, Result. Prefin, III ena, 1967-8. Fubl. Arulser Mus, Pu, Emilio Goeidt Belím, v. 13, p. 15-6, fig. 3-4, 1969.

48 A existōncia de pontas de-projétil pedunculadas e com alotas ou lanceoladas, semelhantes as ia fase Rio Pardinho, na regilio da desembocadura do rio Ibicuí no rio Uruguki, foi observada por P.I. Situmits e a equipe do frstituto Anchictano de Pesquises, ém 1971.

Pontas semelhantes foram ainda observadas pelos dois autores $e$ a equipe do Museu Astropológico "Diretor Pestana", de tjuf, nas proximidades da barragen hielroelétrica do Salto do Tế, em 1922.

a9 SCHMiTZ, Pedro Ignicio e groCHADO, José Proenza. "Datos. ..", p, 7, fê. 1, 2

So MILLER, Eurico Th. "Pesquisas arqueojógicus efetuadas no oeste. ..", ph. 16-7; fig. 8.

S1 SCHMITZ, Pedro Ignífio e BROCHADO, José Proetiza. "Datosc...", p. 11-4, 18-9, fig. 1, 2. 52 id., ibif.

53 "The archacology of Patagonia" In Handbook of Sowth American Indiant, Bureau of American Ethnology, buL, 143, vol. 1, "The Marginal Tribes", p. 17-24. Jelan H. STEWARD (Ed.). Wastington, p. 20, fig 10,1946.

34 SCHOBINGER, Juan. Prehỉstoria de Suramdrics. Barcelona, Laboc, 1969. p. 217.

55 "The Auchacology of the Great Pampa." In Handbook of Sowth A merican Indians, Bareau of American Ethnology, trul, 143, vol, 1, "The Marginal Tribes", p. 25-46. Jalan H. STEWARD (Ed.). Westiegton 1946, p, 32, 12, 13 .

56 SCHOBINGER, Jaan, Oj, cit., p. 212-8.

57 Id, bid. p. 2034, 217, 239, fis. 57.

58 GRADIN, Carlos 3. Contribucabn a la anqueaiogía de la Pampa. Arte Rupeare. La Pampa, Thaseción Provincial de Cultura, 1975- P, 17.

59 GRADIN, Carlos J. "A propósito del arte rupestre en Patagonia Meridional." In Anales de Arqueologie y Etmologia, Mendaza, v, 25, p, 115, 1971.

60 Scqundo 1. Schobinger, op. cit, a cultura Patagoniense seria originaria do sul da Patagonia (P. 204). podendo ser tividida en dois facies regionais, o Surpatagoniense (p. 21.3) e o Nordpatagosiense (p. 21 B) que juntos teriam se estendida desde o estreito do Magalhies até o sul da Província de Buenos Aires (p. $217-8)$.

Scgundo O.F.A. Menghin, citado por J. Schobinger, a cultura Patagoniense pode ser dividida em triss tpocas, descle antes de ca. 1000 z.C. até a época da Canquista.

Patagoniense I - ca. 1000 ב C. até o início đa ers cristã

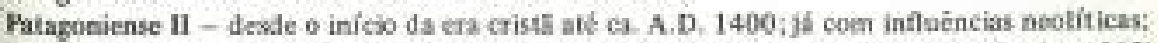

Patagoniense III - ca. A.D. 1400-1700, jă cen contato com os europeus na parte final (p. 218).

0 Patagoniense representaria os caçadores superiores patagǒnicos com pantar-de-projétil Mdunculadas ost apedunculadas. Esta cultura teria, depois de ca. 1000 z C tórios da atual República Oriental do Uruguai e do sal do Hrasil $(p .204)$ até o vale do rio lguaçu, no Estado do Paraní (p. 192, 204, 238, fiq. 51). O scu centro secundário de dispersäo teria sido a regiāo tentro-sul do Lruguai (p. 192, 204). Estes caçadoren superiores pampesnos ou sabpatagóeicos do Urapuaf (p. 192) serium os portadores da indústria títica Subpatagonienso (p. 239) au cultura 
Subpatagoniense ("Chamín") de Entre Rios, do Uruguai (p. 217) e do Rio Grande do Sul (p. 192, 205. fig. 57), que teria perdurado, usando as mesmos tipos de pontas-deprojétil do Patagoniense (fig. 57); desde depois de ca. 1000 a.C. (p. 238 até entrar en contato com os horticultotes e ceramiatas Guarani, em Entre Rios (p. 204) e ro Fio Grande do Sul (p. 192, 239).

"Diversos indf́cios confiman que esta cultura es efectivamente originaria del sas, y que eqle movimiento se contimá́ en dinceción a Brasil, doode encontramos sus elementos hasta el centro de Río

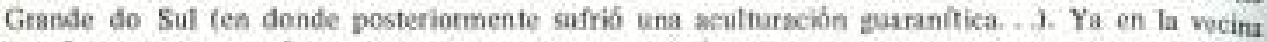
Províacta de Entre Ríos - eatre Jos candalosos Paraní y Urueuay - se encuestran elencntos de la cultura "subpatapónica" charría, y toda la zona muvstra dicho sebstrato cazxdot aun en la época tardia en que se hacen presentes fuertes influencias de culturas sutunitinas y amazónicas, sin contar con la ditima olesda de este oripon, la de los guaranies, grupos de los cinales se establecieton a lo largo de los ríos hasta kas mirgenes superioues del Rio de la Plata" (p. 204).

"A través de los escasos datos arqueológicos podemos entrever, pues, amplas líneas de mieración hacia y desde ta Patagonia. . . Et segundo caso lo constituiría ta 'enigración subpatagónica' a Uruguay y ur de Brasil, cuyo itiberario y época permaseces en complets obscuridad; posiblemeste, no antes del I milenio a. de Jesucristo. Hasta qué punto combios climiticos han influido en estos movimientos, no to sabemos" (p. 239).

61 Ver nota 38.

62 A respeito da tradição Tupiguarani, vit a nota 14.

A respeito da fave Reduçồs, yer a nota 15; đa ceraimxa Neobrasileita. ver a bota 16 e BROCHADO, José Prounz. "Contatos. ..., p. 22.

"... cerámica produzida localmente, com técnicas indigcnas, por popelaçvess miscikenadas de índios, europeus elou africanos. Representa a primcira fase da transiçso da curámica e de nesa da cultura indigena, em direçāo i cultura europçia" (p. 22 ).

A respeito da fase Vacacai e da sua relaça com os índios Tape, ver nota 38

Q3 RIBERO, Pedro Augusto Mentz. "Inscrị̧ōes. . ", p. 113-29.

RIBEIRO, Pedro Augusto Mentz. "Petroglifos..... P. J-14.

RIBEIRO. Pedro Augusto Mentz. "Sitio RS-C-14: Bom Jardim Velho (Abrigo-sob-rocha) - Nota peťvia," In Theringie, Museu Riograndensode CiËncias Naturais, Antropologia n ${ }^{8}$ 2, Porto Alrere, p. $15-58,1972$.

RIBEIRO, Pedro Augusto Mentz. "Os petroglifos. .."

RIBEIRO, Pedro Augusto Mentr. "Primeiras dataçōes pela método C-14 para ó vale do Rio Cal. Rio Grande do SuL." In Rerista do CEPA. Centro de Ensuno é Pesquisa Arqueotógica, Santa Cruz do Sul, v. 2, p, 16-22, 1974 .

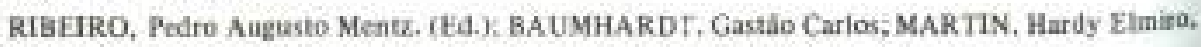
HELSER, Lothar Frederico o STEINHA US, Roberto. "Novos petroglifos. .."

${ }^{64}$ RIBEIRO, Pedro Augusto Mentz, "Sitio..," D. 33-4. MiLLER, Eurico Th. "Pesquisas arqueoKógicas em abrigos-sol-rocha. ..”, fig, 16.

65 RIBEIRO, Pedro Aupusto Mentz. "Os petroglifos, .," p. 7.

65 Cf. Lit. cit. nota 63 .

67 RIBETRO, Pedro Augusto Menti (Ed.); BAUMHARDT, Gastio Cerles; MARTIN, flardy Elmito; HEUSER, Lothar Frederico o STEINHAUS, Robstio, "Novos petroglifos. ..", p. 13.

68 A tradiçî́o cerímica Taquara foi estabelecida no Segundo Seminário do Programa Nackonal de Pesquisas Arqucológicas, rcunido no Musev Paravense Ėmilito Goeldí, em Bejém, de 14 a 29 de julha de 1968. Resultaram as sepuintes publicaçōes:

BROCIIADO, Jose Provecia el atil. "Arqueologis. ..."

PRONAPA. "Brazilian. ..." 
37 GRADIN, Carlos J. "Contribución...," p. 17.

78 GRADIN, Carlos J, "Pictograplas. .,", D, 432-9.

79 MENGHIN, Osvaldo F.A. "Estilos., "., D. 61.

GRADIN, Carlos J. "A propर́sito...", p. 114,

GRADIN, Carlos J. "Contribuciỏn. ..", p. 17.

SCHOBINGER, Juan. Prehistorie, p. 203-4, 217-8, 239, fig. 57 .

so "El arte rupestre..."

81 Tbid., p. $35-5$.

82 Ibid., p. 33, 150.

s3 tbid., D. 34, 154.

84 SCHOBINGER, Juan. Frehteronia, D, 204.

GRADIN, Carlos J. “Pictographs....", p. 431.

"Regions/Pampa/Province of: Duenos Aires/ La Pampa/ Geometric fizures thardly visible)/circular/concentric/with branches/painting: red/white/cavej'sinall hollow" (o grifo é nosso).

s. Id., ibid, p. 428-31.

is SCHOBINGER, Juan, Prehistoria, p. 204.

nge plantea así un interesante problemat el de las causas, cronológia y zona de paso de esta mieración. Esta última debió ser la pampa húmeda, pero curiosamente no encontramos sas huellas en esta anplis región. Tal vez haya que buscarla cn el este de la proviacia de La Pampo, sur de Cótobla y eentro de Santa Fa." 